\title{
Bioactive Metabolites from Marine Algae as Potent Pharmacophores against Oxidative Stress-Associated Human Diseases: A Comprehensive Review
}

\author{
Biswajita Pradhan ${ }^{1}$, Rabindra Nayak ${ }^{1}$, Srimanta Patra ${ }^{2}$, Bimal Prasad Jit ${ }^{3}$, Andrea Ragusa ${ }^{4,5, *(D)}$ \\ and Mrutyunjay Jena ${ }^{1, *}$
}

1 Algal Biotechnology and Molecular Systematic Laboratory, Post Graduate Department of Botany, Berhampur University, Brahmapur 760007, India; pradhan.biswajita2014@gmail.com (B.P.); rabindran335@gmal.com (R.N.)

2 Cancer and Cell Death Laboratory, Department of Life Science, National Institute of Technology Rourkela, Rourkela 769001, India; 518LS2007@nitrkl.ac.in

3 Department of Biochemistry, All India Institute of Medical Science, Ansari Nagar, New Delhi 110023, India; bimaljit2019@gmail.com

4 Department of Biological and Environmental Sciences and Technologies, Campus Ecotekne, University of Salento, via Monteroni, 73100 Lecce, Italy

5 CNR-Nanotec, Institute of Nanotechnology, via Monteroni, 73100 Lecce, Italy

* Correspondence: andrea.ragusa@unisalento.it (A.R.); mj.bot@buodisha.edu.in (M.J.); Tel.: +39-0832-319-208 (A.R.)

Citation: Pradhan, B.; Nayak, R.;

Patra, S.; Jit, B.P.; Ragusa, A.; Jena, M.

Bioactive Metabolites from Marine

Algae as Potent Pharmacophores against Oxidative Stress-Associated Human Diseases: A Comprehensive Review. Molecules 2021, 26, 37. https://dx.doi.org/10.3390/ molecules26010037

Received: 27 November 2020 Accepted: 21 December 2020 Published: 23 December 2020

Publisher's Note: MDPI stays neutral with regard to jurisdictional claims in published maps and institutional affiliations.

Copyright: () 2020 by the authors. Licensee MDPI, Basel, Switzerland. This article is an open access article distributed under the terms and conditions of the Creative Commons Attribution (CC BY) license (https: / / creativecommons.org/ licenses/by/4.0/).
Abstract: In addition to cancer and diabetes, inflammatory and ROS-related diseases represent one of the major health problems worldwide. Currently, several synthetic drugs are used to reduce oxidative stress; nevertheless, these approaches often have side effects. Therefore, to overcome these issues, the search for alternative therapies has gained importance in recent times. Natural bioactive compounds have represented, and they still do, an important source of drugs with high therapeutic efficacy. In the "synthetic" era, terrestrial and aquatic photosynthetic organisms have been shown to be an essential source of natural compounds, some of which might play a leading role in pharmaceutical drug development. Marine organisms constitute nearly half of the worldwide biodiversity. In the marine environment, algae, seaweeds, and seagrasses are the first reported sources of marine natural products for discovering novel pharmacophores. The algal bioactive compounds are a potential source of novel antioxidant and anticancer (through modulation of the cell cycle, metastasis, and apoptosis) compounds. Secondary metabolites in marine Algae, such as phenolic acids, flavonoids, and tannins, could have great therapeutic implications against several diseases. In this context, this review focuses on the diversity of functional compounds extracted from algae and their potential beneficial effects in fighting cancer, diabetes, and inflammatory diseases.

Keywords: marine bioactive compounds; secondary metabolites; algae; oxidative stress; ROS; cancer; diabetes; inflammation; apoptosis

\section{Introduction}

Epidemiological studies have evidenced the dangerous effects on human health of the ever-increasing intake of junk food, alcohol, and antibiotics. This bad behavior can increase the risk of oxidative stress which, in turn, can lead to accelerated aging and inflammatory diseases, such as cardiovascular and neurodegenerative disease and many types of cancer [1]. According to reports by the WHO, more than 200 types of lethal cancer accounted approximately for 9.6 million deaths per year in 2019 globally [2]. Similarly, diabetes mellitus, a metabolic disorder, has emerged as the third foremost cause of death worldwide (1.6 million deaths per year) with several associated ill-fated diseases, such as heart attack, stroke, kidney failure, high blood pressure, blindness, and lower 
limb amputation [3-5]. According to $\mathrm{WHO}$, the world's diabetic population will hike up to 592 million by 2035. In addition to cancer and diabetes, inflammatory diseases have tremendously increased in the recent past causing millions of deaths [6]. Unfortunately, current chemotherapeutic, anti-diabetic, and anti-inflammatory drugs often present several adverse effects, such as toxicity, drug tolerance, and metabolic impairments [1]. In this regard, natural products might provide alternative drugs with better characteristics [7]. Similarly, their regular uptake through diet or novel pharmacological formulations might help prevent oxidative stress-related diseases [8-11].

Approximately 70\% of the Earth's surface is covered by oceans and it hosts an immense variety of marine organisms which represent a rich source of natural products $[1,12,13]$. Marine algae are among the most promising sources of novel bioactive compounds with interesting biological effects, such as antioxidant, anticancer, antibacterial, antifungal, antidiabetic, and anti-inflammatory activities [1]. Marine algae are extensively used in diet and traditional medicine in Asian countries because of the presence of minerals, dietary fiber, lipids, omega- 3 fatty acids, proteins, polysaccharides, and essential amino acids $[14,15]$. They also contain many vitamins, such as vitamins A, B, C, and E [16]. Few marine algae-derived bioactive compounds, such as phlorotannins, polysaccharides, fucoidans, alginic acid, tripeptides, pyropheophytin, and oxylipin, have been shown to reduce the risk of cancer, diabetes, and inflammatory diseases [15]. Hence, in this review we focused our attention on the diversity of marine algal bioactive compounds and the recent findings about their molecular mode of action in potentially fighting cancer, diabetes, and inflammation (Figure 1). Furthermore, algal extracts showed potential antimicrobial activity against aerobes, psychotropic, proteolytic, and lipolytic bacteria and act as natural preservatives. Additionally, they can prevent lipid oxidation $[17,18]$.

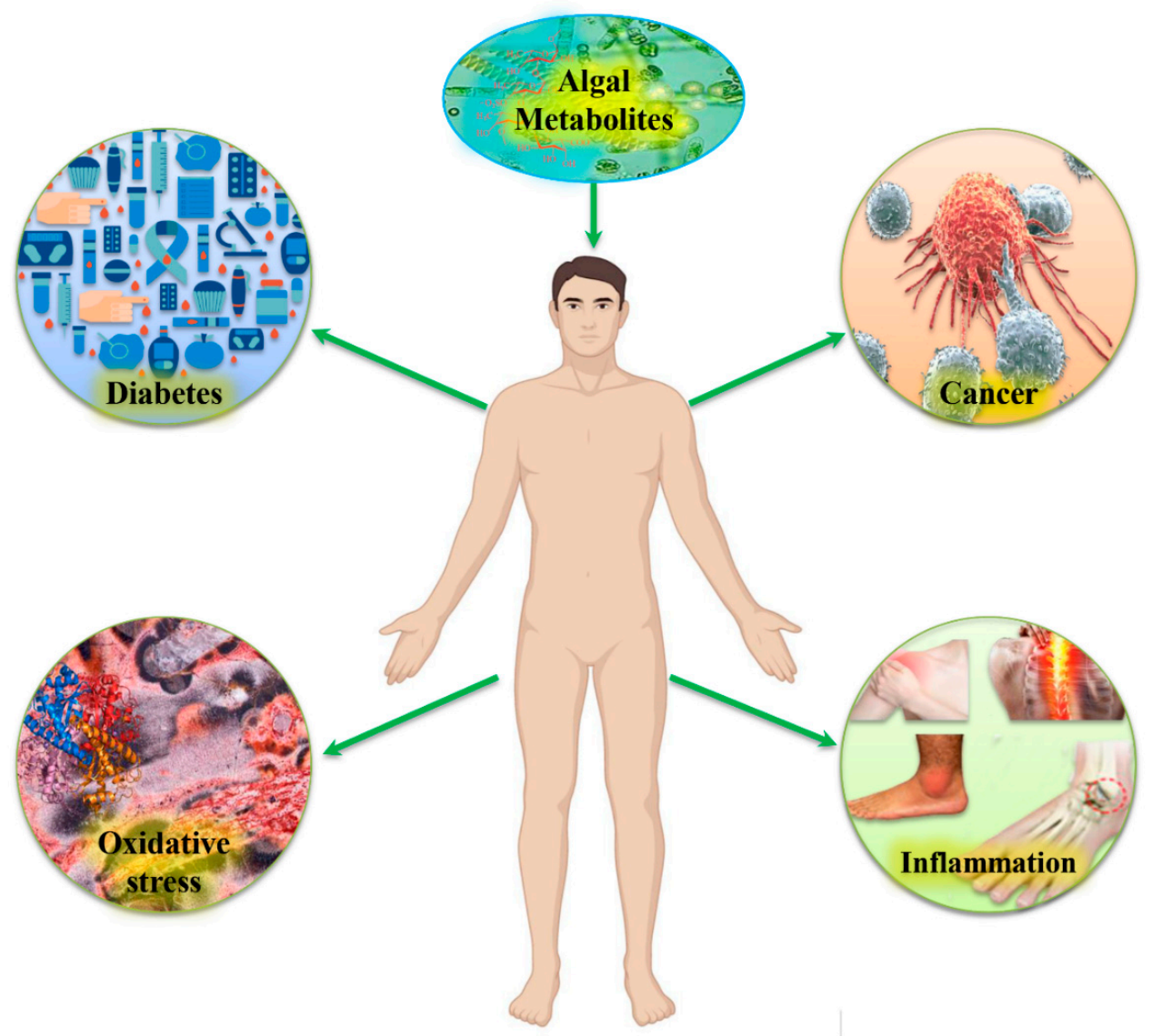

Figure 1. Potential beneficial effects of algal metabolites on human health. Secondary metabolites in marine algae could provide novel drug candidates for fighting various diseases, e.g., by reducing the $\alpha$-amylase and $\alpha$-glucosidase activity in diabetes; by reducing inflammation thanks to their antioxidant capacity; and inhibiting cellular proliferation in tumor cells. 


\section{Biological Activities of Marine Algae and Potential Health Benefits via Dietary Supplements}

Diet plays an important role in disease prevention as more than $33 \%$ of diseases, such as cancer, diabetes, and inflammation-associated chronic diseases, could be avoided by changing lifestyle and food habits $[19,20]$. Nutritional supplements from natural sources could also play an important role in preventing diseases. Phytochemicals from marine algae, such as peptides, amino acids, lipids, fatty acids, sterols, polysaccharides, carbohydrates, polyphenols, photosynthetic pigments, vitamins, and minerals, some of which are represented in Figure 2, can act as potent antioxidants and have beneficial effects as anti-diabetic and chemotherapeutic drugs, as detailed below.<smiles>Oc1cc(O)cc(Oc2c(O)cc(O)c3c2Oc2cc(O)cc(O)c2O3)c1</smiles>

(a)<smiles>Cc1cc(O)c(Oc2cc(O)c3c(c2)Oc2c(O)cc(O)c(Oc4cc(O)cc(O)c4)c2O3)c(O)c1</smiles>

(b)<smiles>Oc1cc(O)cc(Oc2c(O)cc(O)c3c2Oc2c(O)cc(Oc4c(O)cc(O)cc4O)cc2O3)c1</smiles><smiles>Oc1cc(O)c2oc3cc(O)c4oc5cc(O)cc(O)c5oc4c3oc2c1</smiles>

(d)<smiles>CC(C)=COc1c(O)cc(O)c2c1Oc1c(O)cc(O)cc1O2</smiles><smiles>C=C(Cl)/C(Br)=C\CC(Br)=C(C)C</smiles>

(e)

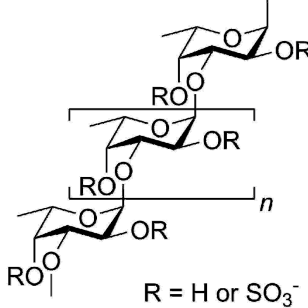

(f)

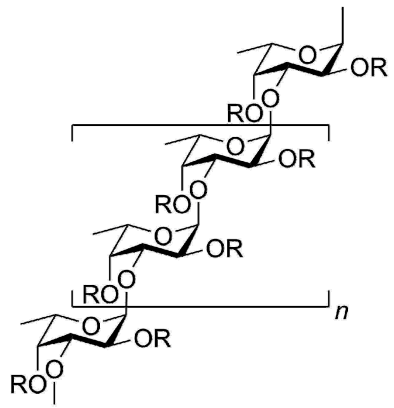

(g)<smiles>C/C=C(/CC[C@H](C)[C@H]1CCC2C3CC=C4CC(O)CC[C@]4(C)C3CC[C@]21C)C(C)C</smiles>

(h)

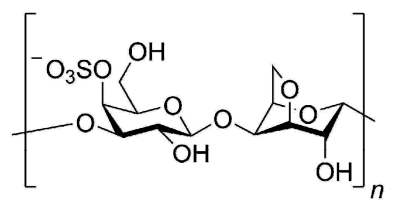

(k)<smiles>CC1=C(/C=C/C(C)=C/C=C/C=C(C)/C=C/C=C(C)/C=C/C=C2C(=O)C(O)CC(C)(C)C(/C=C/C(C)=C/C=C/C3=C(C)C(=O)C(O)CC3(C)C)=C2C)C(C)CC(O)C1=O</smiles><smiles>CC(=O)OC1C[C@H](O)C(C)(C)[C@@H](/C=C/C(C)=C/C=C/C(C)=C/C=C/C=C(C)/C=C/C=C(C)/C(C)=C/CC2C(C)C[C@@H](O)CC2(C)C)C1C</smiles>

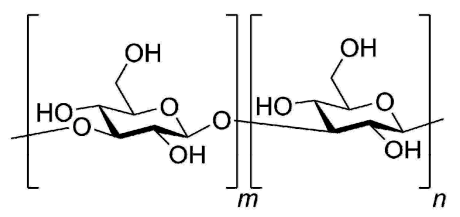

(l)

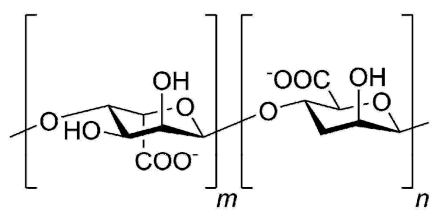

(m)

Figure 2. Chemical structure of several algal metabolites that can have beneficial health effects by acting as antioxidants: (a) eckol, (b) dieckol, (c) 7-phloroeckol, and (d) dioxinodehydroeckol, four phlorotannins; (e) 2-chloro-3-(bromomethylene)-6bromo-7-methyl-1,6-octadiene, a halogenated monoterpene; (f) type I and (g) type II fucoidans; (h) fucosterol; (i) astaxanthin and (j) fucoxanthin; (k) k-carrageenan; (1) laminaran; and (m) alginate. 


\subsection{Peptides and Amino Acids}

Hydrolysis of proteins can lead to bioactive peptides that can present beneficial health aspects and modulate the outcome of the disease. Bioactive phyto-peptides have 3 to 20 amino acid residues and display biological properties such as antioxidant, anticancer, anti-inflammation, and immunomodulation. For example, purified peptides from Chlorella vulgaris can prevent cellular damage and can act as potent anticancer agents [21,22].

The protein content in macro and micro algae comprises all essential amino acids which prevent cellular damage. The red alga Palmaria palmata is rich in Leu, Val, and Met, and their mean levels are similar to ovalbumin. Similarly, Ile and Thr concentrations are comparable to those in legume proteins. The green alga Ulva rigida contains Leu, Phe, and Val as major essential amino acids $[23,24]$.

\subsection{Lipids and Fatty Acids}

The structural complexity of lipids and fatty acids are highly diverse and contribute to their therapeutic efficacy. It has been reported that small amounts of saturated fatty acids can help prevent cardiovascular diseases. Marine algae contain polyunsaturated fatty acids (PUFAs) and significant amounts of monounsaturated fatty acids which are beneficial to human health and could help reduce cardiovascular diseases [25].

\subsubsection{Polyunsaturated Fatty Acids (PUFAs)}

Humans are incapable of synthesizing PUFAs that, on the other hand, are abundant in both macro and microalgae. PUFAs in microalgae are mainly composed of omega- 3 and omega- 6 fatty acids (e.g., EPA and AA) [26]. PUFAs regulate blood clotting and blood pressure and modulate the function of the brain and nervous systems [27]. Moreover, they decrease the risk of several chronic diseases, such as diabetes and cancer. Additionally, they regulate inflammatory responses by producing eicosanoids, well-known inflammation mediators [27]. Omega-3 and omega-6 PUFA from macroalgae are already used as dietary supplements [28]. Red and brown algae have a high level of omega-3 fatty acids (e.g., EPA and GLA) and omega- 6 fatty acids (e.g., AA and linoleic acid). Brown algae Laminaria ochroleuca and Undaria pinnatifida are a rich source of octadecatetraenoic acid, an omega-3 PUFA [29]. Green seaweed Ulva pertusa was found to be rich in hexadecatetraenoic (omega-3), oleic (omega-9), and palmitic acids (SFA). The lipid fraction of microalgae C. vulgaris contains oleic, palmitic, and linolenic acids. The green microalga Haematococcus sp. also contains short-chain fatty acids. Long-chain PUFAs are also used as nutritional supplements and food additives [30]. Spirulina sp. is a promising source of GLAs, a precursor of leukotrienes, prostaglandins, and thromboxans that regulate inflammatory, immunological, and cardiovascular disorders. Cyanobacteria and some green algae also contain bioactive fatty acids such as palmitic, oleic, and lauric acids along with DHA [22].

\subsubsection{Sterols}

Sterols are a class of lipids extensively found in both macro and microalgae. Sterols and some of their derivatives have potential biological, e.g., anti-inflammatory, activity. Sterols from Spirulina triggers the formation of the plasminogen-activating factor in vascular endothelial cells. Fucosterol, ergosterol, and chondrillasterol are found in brown algae and cholesterol has been found in red algae [22,31].

\subsection{Polysaccharides and Carbohydrates}

Polysaccharides are abundant in seaweeds and also found in microalgae. They generally comprise about $4 \%$ to $76 \%$ of the total dry weight of the alga. Polysaccharides are classified according to their chemical structure, such as sulfuric acid polysaccharides, sulfated xylans, and galactans (generally found in green algae). Moreover, alginic acid, fucoidan, laminarin, and sargassan are found in brown algae [32]. Agar, carrageenans, xylans, and floridean are generally found in red algae. Many algal polysaccharides present bioactivity and could become drug candidates with potential use in several human health 
disparities [33]. Carrageenans are sulfated galactans and they are extensively used in pharmaceutical and food industries. Soluble fibers such as fucans, alginates, and laminarans are found in brown seaweeds, whereas soluble fibers such as sulfated galactans (agars and carrageenans), xylans, and floridean starch are abundantly found in red seaweeds [34]. Green algae contain xylans, mannans, starch, and ionic sulfate group-containing polysaccharides in combination with uronic acids, rhamnose, xylose, galactose, and arabinose. Many of the polysaccharides can be regarded as dietary fibers and are classified into two groups, i.e., soluble and insoluble fibers [35,36]. Seaweeds contain about $25 \%$ to $75 \%$ dietary fibers in comparison to their dry weight, a higher percentage compared to that found in fruit and vegetables [37]. The algal dietary fiber consumption has several health benefits as they can be used as antitumor, anticancer, anticoagulant, and antiviral agents. Fucoidans are extensively found in the cell walls of brown macroalgae [38]. Fucoidans have several biological activities and act as antioxidant, antitumor, anti-inflammatory, antidiabetes, antiviral, anticoagulant, and antithrombotic agents. Additionally, they also modulate the human immune system [1]. Furthermore, laminarin is the second main source of glucan, abundantly found in brown algae, and it acts as a facilitator of intestinal metabolism [36].

Carbohydrates, such as glucose and starch, are abundantly found in microalgae [39]. Many biological functions of microalgal species are due to the presence of carbohydrates. Chlorella pyrenoidosa and Chlorella ellipsoidea contain glucose and a wide variety of combinations of galactose, mannose, rhamnose, $\mathrm{N}$-acetylglucosamine, $\mathrm{N}$-acetylgalactosamine, and arabinose that exert immune-modulatory and antiproliferative activity [40]. $\beta-1,3-$ Glucans extracted from Chlorella have been shown to act as immunomodulators that can reduce blood lipids [41].

\subsection{Polyphenolic Compounds}

Marine algal bioactive compounds are potent antioxidant agents that protect from oxidative damage [42]. The antioxidant activity of bioactive compounds from marine algae is associated with protection against cancer, inflammatory, diabetes, and several ROS-related diseases [43]. Polyphenolic compounds are mainly found in both micro and macroalgae [42]. The phenolic components include hydroxycinnamic acids, phenolic acids, simple phenols, xanthones, coumarins, naphthoquinones, stilbenes, flavonoids, anthraquinones, and lignins [21]. The phlorotannins with potential antioxidant activity belong to polyphenolic compounds that have been screened from several brown algae. Phlorotannins are known for their chemopreventive, antibacterial, antiproliferative, and UV-protective properties [22].

\subsection{Photosynthetic Pigments}

Macroalgae contain chlorophylls and carotenoids as major photosynthetic pigments. Carotenoids are well known for their antioxidant properties and dietary carotenoids have high nutritional and therapeutic value [44]. Carotenoids are well known for their chemopreventive effect against several cancer subtypes. Microalgae are also the main source of antioxidants such as $\beta$-carotene and astaxanthin. $\beta$-Carotene is a natural colorant that has been conventionally used as food and drinks colorants and can act as dietary food supplements or additives with a high antioxidant capacity [45].

\subsection{Vitamins and Minerals}

Vitamins are micronutrients essential for human body growth and development. Seaweeds and microalgae are known to be a good source of vitamin B1, B2, and B12. Vitamin B12 (cobalamin) is extensively found in higher concentrations in green and red algae compared to brown algae [46]. Vitamin B12 is generally found in red macroalgae such as Palmaria longat and Porphyra tenera. The highest vitamin B12 content was found in red seaweed Porphyra sp. and green algae, such as Enteromorpha sp. and Spirulina. Cobalamin deficiency can cause health diseases, such as neuropsychiatric disorders and megaloblastic anaemia. Vitamin C (ascorbic acid) is present in all red, brown, and green seaweeds. Vitamin $C$ has several health benefits, such as radical scavenging activity, antiaging, and im- 
mune stimulant activity. Vitamin E is a mixture of tocopherols. $\alpha$ Tocopherol occurs in green, red, and brown seaweeds. Phaeophyceae also contain $\beta$ - and $\gamma$-tocopherols and displayed outstanding antioxidant activity. Vitamins $C$ and $E$ were also found in Laminaria digitata and U. pinnatifida [22].

Seaweeds and macroalgae are rich in minerals, trace elements, and maintain inorganic atoms in seawater. Minerals and trace elements are required for the human diet [47]. Phaeophyceae, such as U. pinnatifida and Sargassum, and rhodophyta, such as Chondrus crispus and Gracilariopsis, are considered dietary supplement that meet the recommended daily intake of some of the major minerals, such as $\mathrm{Na}, \mathrm{K}, \mathrm{Ca}$, and $\mathrm{Mg}$, as well as trace minerals, such as $\mathrm{Fe}, \mathrm{Zn}, \mathrm{Mn}$, and $\mathrm{Cu}$. In addition, seaweeds are also important sources of $\mathrm{Ca}$ as they reduce $\mathrm{Ca}$ deficiency risk in pregnant women and adolescents and they inhibit preadolescent aging [48].

\section{Marine Bioactive Metabolites and Their Therapeutic Efficacy}

The marine ecosystem is a source of novel natural secondary metabolites with promising biomedical applications [49]. The impact of marine algae in the area of traditional medicine is huge and they have been used as Yunani hakim in many countries, such as China and Egypt. Marine algae produce diverse secondary metabolites and might be the most promising sources of proteins, vitamins, omega-3, carotenoids, phenolic acids, and flavonoids, as well as other natural antioxidants [50]. These marine bioactive compounds act as free radical scavengers and prevent oxyradical formation thus reducing oxidative stress and, as such, they have great importance in the prevention of cancer, diabetes, early aging, and several other inflammatory diseases (Figure 3).

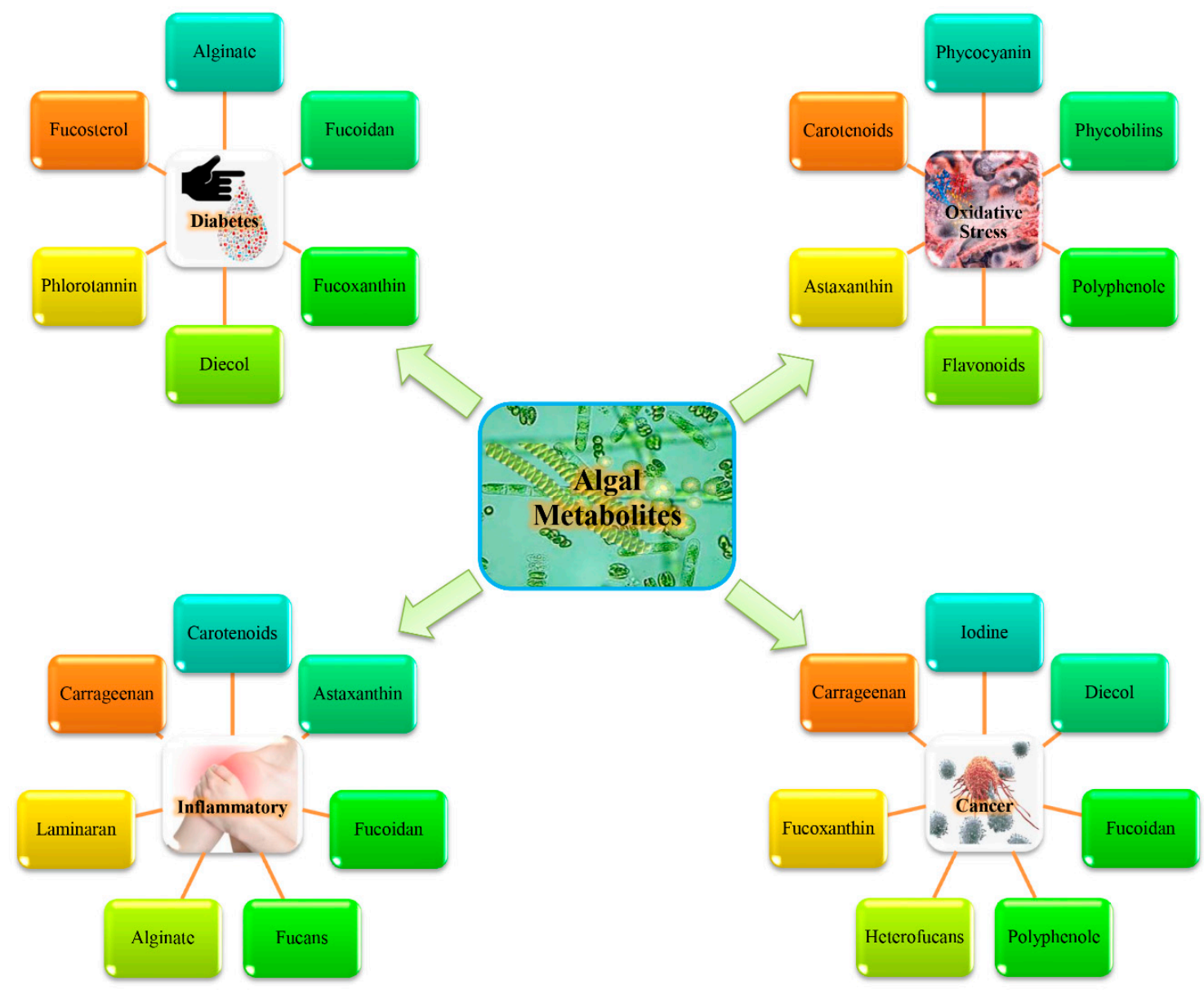

Figure 3. Potential effects of algal metabolites in different human disease. 
Marine bioactive compounds, such as algal photosynthetic pigments, phycobiliproteins, carotenoids, polyphenols, terpenes, phlorotannins, and polysaccharides, have shown promising therapeutic activity in both in vitro and in vivo models $[25,29,38,51]$.

\subsection{Marine Bioactive Metabolites and Modulation of In Vitro Antioxidant Activity}

Reactive oxygen species (ROS) comprise a group of oxygenic ions that are highly reactive and pose a serious threat to biological components, ultimately leading to serious disorders such as cancer, diabetes mellitus, neurodegenerative and inflammatory diseases [52]. The oxygen-containing radicals comprise of peroxyl $\left(\mathrm{ROO}^{\bullet}\right)$, hydroxyl $\left(\mathrm{OH}^{\bullet}\right)$, hydroperoxyl $\left(\mathrm{HO}_{2}{ }^{\bullet}\right)$, superoxide $\left(\mathrm{O}_{2}{ }^{\bullet}\right)$, alkoxyl $\left(\mathrm{RO}^{\bullet}\right)$, thiyl peroxyl ( $\left.\mathrm{RSOO}{ }^{\bullet}\right)$, sulfonyl $\left(\mathrm{ROS}^{\bullet}\right)$, and nitric oxide $\left(\mathrm{NO}^{\bullet}\right)$ radical, as well as non-radical oxidizing agents such as singlet oxygen $\left({ }^{1} \mathrm{O}_{2}\right)$, hydrogen peroxide $\left(\mathrm{H}_{2} \mathrm{O}_{2}\right)$, hypochlorous acid $(\mathrm{HOCl})$, and organic hydroperoxides (ROOH) [52-55]. Cells can detoxify ROS as they are furnished with antioxidant defense mechanisms to maintain cellular equilibrium. Antioxidants fight against ROS and exert a positive effect on human health by protecting macromolecules such as proteins, DNA, and membrane lipids [56]. The use of synthetic antioxidants used as food additives, such as butylated hydroxyanisole, butylated hydroxytoluene, tertiary-butylhydroquinone, and propyl gallate, might represent a threat because of their side effects [57]. Hence, the development of novel antioxidants from natural sources like marine flora can represent a promising approach. Marine algae could neutralize ROS because of their antioxidant compounds, such as phycobilins, phycocyanin, carotenoids, astaxanthin, polyphenols, and vitamins, which can act against cancer, diabetes, inflammation, aging, and immune responses. The antioxidant capacity of various marine algae, such as green, red, and brown algae species, has been already extensively reported in the literature.

Antioxidant activity of marine algal compounds have been determined by several methods, such as 2,2-diphenyl-1-picrylhydrazil (DPPH) radical scavenging, ferric reducing antioxidant power (FRAP), lipid peroxide inhibition, ABTS radical scavenging, nitric oxide (NO) scavenging, hydrogen peroxide radical scavenging assays, superoxide radical and hydroxyl radical scavenging assays. The methanolic extract of blue-green algae has shown potent DPPH radical scavenging activity. In addition, phycocyanin from Spirulina platensis showed strong $\mathrm{H}_{2} \mathrm{O}_{2}$ scavenging activity [58]. Antioxidant properties in green algae Ulva fasciata and Ulva reticulate were characterized by free-radical-scavenging due to the presence of flavonoids [59-61]. In brown algae such as Ecklonia cava, Eisenia bicyclis, and Ecklonia kurome antioxidant activities were characterized by DPPH-radical scavenging [62]. Ethanolic extracts of Gracilaria tenuistipitata and Callophyllis japonica also have shown potential antioxidant activities [63,64].

\subsection{Intricate Role of Algal Bioactive Metabolites as Anticancer Agents}

Free radicals and ROS generally promote cancer initiation. Synthetic chemopreventive drugs often present several adverse side-effects to the tumor vicinity and bodily organs because of poor specificity and generalized biodistribution [65]. Several marine algal bioactive compounds have been designated as potent chemopreventives due to inhibition of cellular proliferation, modulation of the cell cycle, and induction of apoptosis [66,67].

\subsubsection{Inhibition of Cell Proliferation}

Several studies have reported that marine algal bioactive compounds have antiproliferative and inhibitory activity against several cancer subtypes in in vitro as well as in vivo [68]. Sulfated polysaccharides purified from brown seaweeds exhibited an antiproliferative effect on human leukemia and lymphoma cell lines [38]. They have also been reported to inhibit proliferation of breast (MCF-7) and cervical (HeLa) cancer cells [38]. Sulfated polysaccharides extracted from the brown seaweed Sargassum vulgare displayed inhibition of cell proliferation in HeLa and B16 cells without cytotoxicity in normal rabbit aortic endothelial cells [69]. Furthermore, sulfated polysaccharides from red seaweed Amansia multifidi inhibited the cellular viability of HeLa cells. The polysaccharides isolated 
from Gracilariopsis lemaneiformis, consisting of 3,6-anhydro-L-galactose and D-galactose and a linear structure of repeated disaccharide agarobiose units, hindered the viability of B16, A549, and MKN-28 cell lines [70]. Similarly, low-molecular-weight sulfated polysaccharides from green seaweed Gayralia oxysperma inhibited the cell viability of U87MG glioblastoma cells even at microgram-level concentrations $(10,100$, and $1000 \mu \mathrm{g} / \mathrm{mL})$ without any evident cytotoxicity [71]. Fucoidans isolated from Undaria pinnatifida also showed inhibition of cellular viability in SK-MEL-28, T-47, RPMI-7951, T47D, and DLD-1 cancer cell lines at microgram concentrations. Moreover, fucoidans isolated from the sporophyll of $U$. pinnatifida demonstrated to be able to inhibit cell growth in HeLa, A549, PC-3, and HepG2 cell lines, although at higher concentrations (treatment with $0.8 \mathrm{mg} / \mathrm{mL}$ for $24 \mathrm{~h}$ ) [72]. Furthermore, in prostate cell lines (DU-145), fucoidans treatment marked a $90 \%$ reduction in cell viability [73]. Similarly, Fucus vesiculosus derived fucoidans were reported to reduce cell viability of human colorectal carcinoma (HCT116) cell line by $60 \%$ [74]. Fucoidan from Ecklonia cava have been also reported to inhibit proliferation of MDA-MB-231 cells. Moreover, the administration of fucoidan ( $20 \mathrm{mg} / \mathrm{kg}$ for 28 days) in a DU- 145 cell-induced xenograft rat model has reduced the tumor growth by 50\% [73]. Carrageenans from Kappaphycus alvarezii reduced the growth of liver, colon, breast, and osteosarcoma cell lines [75]. Similarly, treatment of phlorotannins (a type of polyphenol) isolated from E. cava has marked a reduction in cell viability in MDA-MB-231 and MCF-7 cells by $55 \%$ and $64 \%$, respectively [76]. Similarly, phlorotannin-rich extracts from Ascophyllum nodosum reduced the cell viability of HT-29 colon cancer cells [77].

Halogenated monoterpenes isolated from red seaweeds Plocamium cornutum and Plocamium suhrii displayed potent antiproliferative activity as compared to anticancer drug cisplatin [78]. U. pinnatifida isolated fucoxanthins has a cytotoxic effect against LNCaP, DU145, PC-3, Caco-2, HT-29, DLD-1, HeLa, and Jurkat cell lines [79,80]. Moreover, fucoxanthinol displayed an anti-proliferative effect against drug-resistant HT-29-derived cells, and inhibited xenograft tumor development in a dose-dependent manner [81]. The guaiane sesquiterpene derivative guai-2-en-10-ol isolated from the green seaweed Ulva fasciata, reduced viability of breast cancer MDA-MB-231 cell line [82]. G. tenuistipitata aqueous extract counteracted the cellular proliferation in H1299 cells. Heterofucans from Sargassum filipendula exhibited anti-proliferative effects on cervical, prostate, and liver cancer cells [83]. Aqueous extracts of Sargassum oligocystum and Gracilaria corticata inhibited proliferation of human leukemic cell lines [84,85]. Ethanolic and methanolic extracts of Gracilaria tenuistipitata exhibited anti-proliferative effects against Ca9-22 oral cancer cells [86-88]. Several studies have reported that algae consumption modulates cancer prevention. The diets containing seaweeds decreased the growth of DU-145 human prostatic tumor cells in nude mice. Moreover, the administration of red algae Eucheuma cottonii extracts as dietary supplement to rats displayed tumor repression [89].

\subsubsection{Cell Cycle Arrest and Inhibition of Angiogenesis}

Inhibition of cell cycle hinders cancer cell proliferation for the subsequent exhibition of anticancer activity. Sulfated polysaccharides from G. oxysperma arrested the cell cycle [71]. Fucoidan from Fucus vesiculosus arrested the cell cycle at the G1 phase in HCT116 human colorectal carcinoma and HT-29 colon cancer cells [74]. Fucoxanthin arrested the cell cycle via downregulation of cyclin D1, D2, CDK4 and upregulation of p15INK4B and p27Kip1 expression [90]. Fucoxanthin from Laminaria japonica arrested the sub-G1 phase of the cell cycle in WiDr cancer cells [91]. Moreover, in LNCap prostate cancer cells, fucoxanthin arrested the G1 phase of the cell cycle via MAPK/ JNK and GDD45A pathways [92]. Pheophorbide a, from G. elliptica arrested the cell cycle in the G0/G1 phase in glioblastoma cells [93]. Aqueous extract of G. tenuistipitata induced G2/M arrest in the H1299 cell line [64]. Angiogenesis plays a key role in tumor growth and metastasis. Polysaccharides isolated from S. vulgare exhibited angiogenesis inhibitory activity. Fucoidans isolated from $U$. pinnatifida significantly reduced the expression of the angiogenesis factors VEGF-A and VEGF-162 [94]. Sulfated polysaccharides from brown seaweed Sargassum vulgare displayed antiangiogenic 
activity in HeLa and B16 cells without damage to the tumor vicinity [69]. Furthermore, dieckol decreased the expression of angiogenic markers such as PCNA, VEGF, COX-2, MMP-2, and MMP-9 to inhibit metastasis [95].

\subsubsection{Induction of Apoptosis}

Apoptosis (or programmed cell death, PCD) is the main goal of anticancer drugs. Several reports have demonstrated the role of algal bioactive compounds and polysaccharides as potent anticancer agents by modulating apoptosis, as schematized in Figure 4 . Sulfated polysaccharides from Phaeophyceae act as novel chemopreventive drugs owing to their free-radical scavenging activity [1]. Sulfated polysaccharides induced apoptosis in human leukemic monocyte lymphoma cell line (U-937) [1]. Polysaccharides from Capsosiphon fulvescens induced apoptosis in gastric cancer cells via modulation of PI3K/Akt pathway [96]. Polysaccharides from $U$. lactuca increased the activity of antioxidant enzymes in a DMBA-induced breast cancer model via diminished lipid peroxidation as well as GSHPx activity to restrain apoptosis [97]. Polysaccharides from red seaweed Champia feldmannii demonstrated in vivo antitumor effects in mice transplanted with sarcoma 180 tumors via modulation of apoptosis [98]. The polysaccharides isolated from sea lettuce $U$. lactuca displayed in vitro and in vivo anticancer activity in breast cancer via modulation of apoptosis. It also displayed a chemopreventive effect in DMBA-induced breast cancer in rat post-administration for 10 weeks and prevented breast-histological alterations and carcinogenic wounds. Additionally, it also amplified the p53 expression and inhibited the $\mathrm{Bcl}-2$ expression to induce apoptosis in breast cancer cells [97].

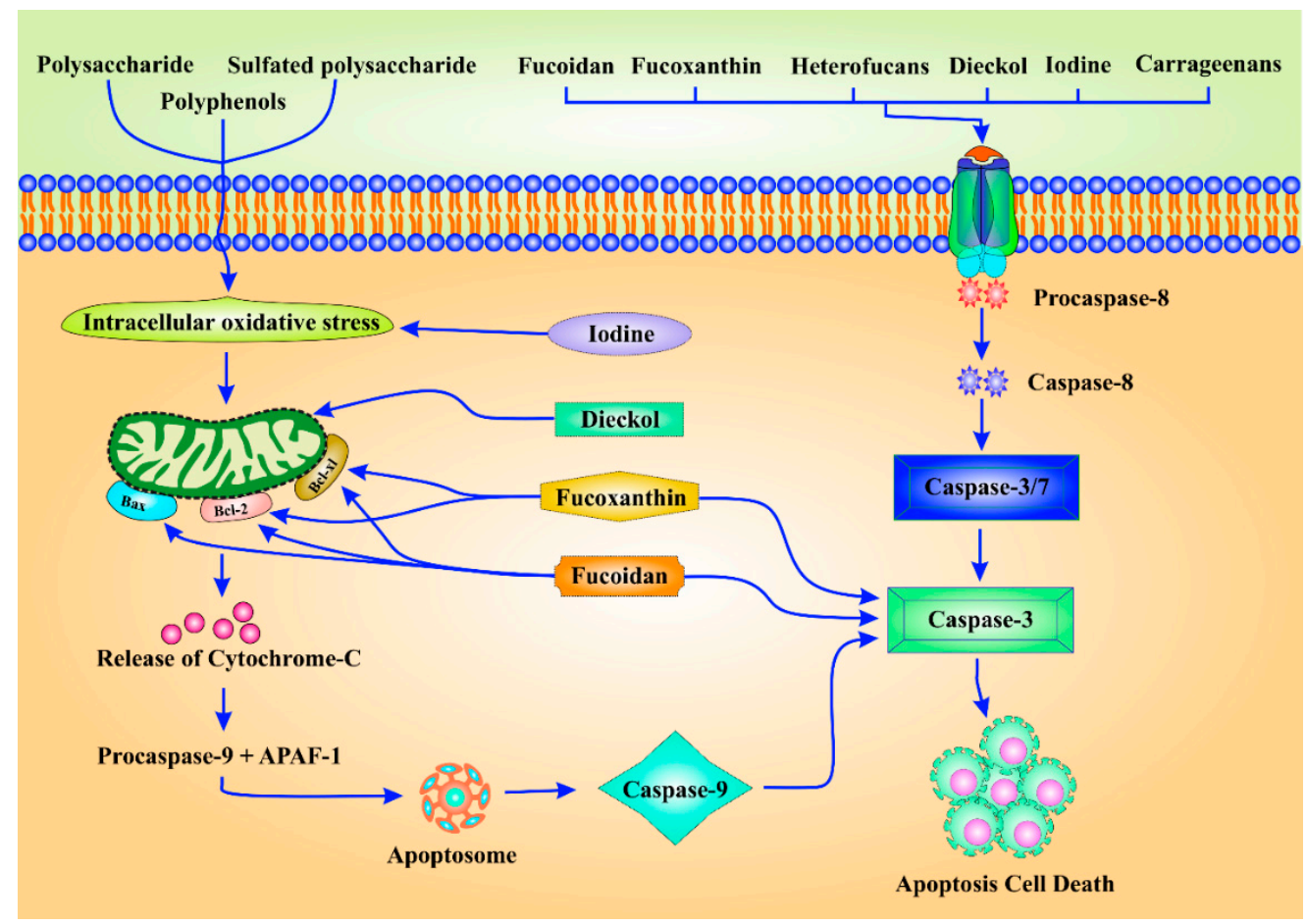

Figure 4. Apoptosis modulation by algal metabolites in cancer prevention. Polysaccharides, sulfated polysaccharides, iodine, dieckol, fucoxanthine, fucoidan, and polyphenols downregulate the expression of anti-apoptotic protein Bcl-xl, Bcl-2. Similarly, they enhance the Bax expression to aid apoptosis. Fucoidan supports the intrinsic apoptosis via regulating the cytosolic release of cytochrome $\mathrm{C}$. Fucoxanthine and fucoidan induces the expression of caspase 9 and caspase 3 to induce apoptotic cell death. Moreover, fucoidan, fucoxanthine, heterofucans, dieckol, iodine, and carrageenans induce apoptosis through modulation of caspase 3 activity via death receptor-mediated apoptotic cell death in several cancer cell lines. In addition to this, they also regulate caspase 8 activity inducing extrinsic apoptosis in different cancer cells. 
Fucoidans isolated from the sporophyll of $U$. pinnatifida displayed apoptosis in DU-145 cell-induced xenograft rat model via inhibition of the JAK3/STAT pathway. In addition, fucoidan $\left(\mathrm{IC}_{50} 530 \pm 3.32 \mathrm{mg} / \mathrm{mL}\right.$ ) also reduced the viability of B16 melanoma cells via activating apoptosis [99]. Fucoidan from Fucus vesiculosus induced p53-independent apoptosis in HCT116 human colorectal carcinoma cell line [74]. Fucoidan from L. japonica induced apoptosis via activation of caspase-3, poly(ADP-ribose) polymerase (PARP), and DNA degradation in HT-29 cell line [100]. Moreover, fucoidan from E. cava induced apoptosis in MDA-MB-231 and MCF-7 cells via induction of p53 and activation of Bax, caspases 3 and 9, and PARP with inhibition of Bcl-2 [76]. Furthermore, fucoidan from Cladosiphon okamuranus displayed induction of apoptosis in MCF-7 cells via activation of caspase-3 and DNA fragmentation [101]. F. vesiculosus extracts enhanced mitochondria membrane permeability thus inducing apoptosis via cytoplasmic release of cytochrome C and the Smac/DIABLO pathway in human colon cancer cells [102]. Similarly, fucoidan from F. vesiculosus treatment induced apoptosis in HT-29 colon cancer cells via decreasing the expression of Bcl-xL, Bcl-2 and upregulation of Bax, pro-caspases 3, 7, and 9. An upregulation of $\mathrm{Rb}$ and E2 factor proteins and Fas-regulated extrinsic apoptosis was also evident post fucoidan treatment in HT-29 colon cancer cells [103].

Fucoxanthin from Laminaria japonica induced apoptosis via DNA fragmentation in human colon adenocarcinoma WiDr cells [91]. Fucoxanthin from Ishige okamurae exhibited anticancer activity in melanoma B16F10 cells both in vitro (B16F10 cell line) and in vivo (Balb/c mice implanted with B16F10 cells) via induction of apoptosis. Moreover, fucoxanthin induced apoptosis via caspases activation and reduction of BclxL and IAP expression [90]. Laminarin from Laminaria digitata induced apoptosis in human colon cancer (HT-29) cells and activated ErbB2 phosphorylation. Moreover, it also inhibited cell proliferation and induced apoptosis in prostate cancer (PC-3) cells and increased the expression of P27kip1 and PTEN [104]. Dieckol from E. cava daily administration (40 mg/kg for 15 weeks) decreased cancer cell proliferation in albino rats via induction of apoptosis [95]. The guaiane sesquiterpene derivative guai-2-en-10-ol from green seaweed Ulva fasciata induced apoptosis in MDA-MB-231 breast cancer cell line via direct interaction with the kinase site of EGFR [82]. The halogenated monoterpene, mertensene from red alga Pterocladiella capillacea induced apoptosis in HT-29 and LS174 via modulation of ERK1/2, Akt, and NF B pathways [78]. Ethanolic and methanolic solvent extracts of Gracilaria tenuistipitata displayed apoptosis in Ca9-22 oral cancer cells via DNA damage. Furthermore, methanol extract of Plocamium telfairiae induced caspase-dependent apoptosis in HT-29 colon cancer cells [88]. Iodine and polyphenols from L. japonica induced apoptosis via inhibiting SOD activity [105]. The red alga Porphyra yezoensis can induce cancer cell death via apoptosis in a dose-dependent manner in in vitro cancer cell lines without exhibiting cytotoxicity towards the normal cells. Moreover, Carrageenans, heterofucans, dieckol, and iodine can induce cancer cell death via apoptosis in a dose-dependent manner in in vitro cancer cell lines without exhibiting cytotoxicity towards the normal cells. Furthermore, L. japonica water extracts induced apoptosis in several human breast cancer cell lines. Moreover, Eucheuma cottonii extract displayed the upregulation of antioxidant enzymes such as catalase (CAT), superoxide dismutase (SOD), glutathione peroxidase (GPx) in cancer-induced rats [89]. Methanolic extracts of Fucus serratus and F. vesiculosus exhibited protection of DNA damage induced by $\mathrm{H}_{2} \mathrm{O}_{2}$ in Caco-2 cells [106]. Furthermore, Pelvetia canaliculata inhibited $\mathrm{H}_{2} \mathrm{O}_{2}$-induced superoxide dismutase depletion in Caco-2 cells [106]. C. japonica ethanol extracts inhibited $\mathrm{H}_{2} \mathrm{O}_{2}$-induced apoptosis via activating cellular antioxidant enzymes [63]. G. tenuistipitata aqueous extract enhanced the recovery of these cells from $\mathrm{H}_{2} \mathrm{O}_{2}$-induced DNA damage in the $\mathrm{H} 1299$ cell line [59]. Apoptosis modulation by algal metabolites in different cancerous cell lines with molecular pathways are summarized in Table 1. 
Table 1. Marine algal bioactive metabolites and their functional role in apoptosis.

\begin{tabular}{|c|c|c|c|c|c|}
\hline & Bioactive Compounds & Algal Sources & Cell Lines/In Vivo Models Involved & Functional Involvement & Ref. \\
\hline 1 & Sulfated polysaccharides & Brawn algae & Human leukemic monocyte lymphoma cell line (U-937) & Inhibition of cell proliferation & [1] \\
\hline 2 & Polysaccharides & Capsosiphon fulvescens & Gastric cancer cells & Modulation of PI3K/Akt pathway & [96] \\
\hline 4 & Polysaccharides & Champia feldmannii & Mice transplanted with sarcoma 180 tumors & Reduction of tumor growth & [98] \\
\hline 5 & Polysaccharides & U. lactuca & DMBA-induced breast cancer in rat & $\begin{array}{l}\text { Prevented breast-histological alterations and carcinogenic } \\
\text { wounds }\end{array}$ & [97] \\
\hline \multirow{2}{*}{7} & \multirow{2}{*}{ Fucoidan } & \multirow{2}{*}{ Costaria costata } & DLD-1 & $55 \%(100 \mu \mathrm{g} / \mathrm{mL})$ & [107] \\
\hline & & & SK-MEL-28 & $20 \%(100 \mu \mathrm{g} / \mathrm{mL})$ & [107] \\
\hline 8 & Fucoidans & U. pinnatifida & DU-145 cell-induced xenograft rat model & Inhibition of the JAK3/STAT pathway & [99] \\
\hline 9 & Fucoidan & Fucus vesiculosus & HCT116 human colorectal carcinoma cell line & p53-independent & {$[74]$} \\
\hline 10 & Fucoidan & L. japonica & HT-29 cell line & Caspase-3, PARP, and DNA degradation & [100] \\
\hline 11 & Fucoidan & E. cava & MDA-MB231 and MCF-7 cells & $\begin{array}{c}\text { Induction of p53 and activation of Bax, caspases } 3 \text { and 9, } \\
\text { and PARP with inhibition of Bcl-2 }\end{array}$ & [76] \\
\hline 12 & Fucoidan & Cladosiphon okamuranus & MCF-7 cells & Activation of caspase- 3 and DNA fragmentation & [101] \\
\hline 13 & Extracts & F. vesiculosus & Human colon cancer cells & $\begin{array}{l}\text { Cytoplasmic release of cytochrome } \mathrm{C} \text { and the } \\
\text { Smac/DIABLO pathway }\end{array}$ & [102] \\
\hline 14 & Fucoidan & F. vesiculosus & HT-29 colon cancer cells & $\begin{array}{l}\text { Decreased expression of Bcl-xL, Bcl-2 and upregulation of } \\
\text { Bax, pro-caspases } 3,7 \text {, and } 9\end{array}$ & [103] \\
\hline 15 & Fucoidan & F. vesiculosus & HT-29 colon cancer cells & $\begin{array}{c}\text { Upregulation of } \mathrm{Rb} \text { and } \mathrm{E} 2 \text { factor proteins and Fas } \\
\text { regulation }\end{array}$ & [103] \\
\hline 16 & Fucoxanthin & Laminaria japonica & Human colon adenocarcinoma WiDr cells & DNA fragmentation & [91] \\
\hline 17 & Fucoxanthin & Ishige okamurae & Melanoma B16F10 cells & $\begin{array}{l}\text { Caspases activation and reduction of BclxL and IAP } \\
\text { expression }\end{array}$ & {$[90]$} \\
\hline 18 & Dieckol & E. cava & Albino rats & Decreased cancer cell proliferation & [95] \\
\hline
\end{tabular}


Table 1. Cont.

\begin{tabular}{|c|c|c|c|c|c|}
\hline & Bioactive Compounds & Algal Sources & Cell Lines/In Vivo Models Involved & Functional Involvement & Ref. \\
\hline 19 & Guaiane sesquiterpene & Ulva fasciata & MDA MB-231 breast cancer cell line & Direct interaction with kinase site of EGFR & [82] \\
\hline 20 & $\begin{array}{l}\text { Halogenated monoterpene, } \\
\text { mertensene }\end{array}$ & Pterocladiella capillacea & HT-29 and LS174 & ERK1/2, Akt, and NF B pathways & [78] \\
\hline 21 & $\begin{array}{l}\text { Ethanolic and methanolic } \\
\text { extracts }\end{array}$ & Gracilaria tenuistipitata & Ca9-22 oral cancer cells & DNA damage & {$[88]$} \\
\hline 22 & Methanolic extract & Plocamium telfairiae & HT-29 colon cancer cells & Induced caspase-dependent & [88] \\
\hline 24 & Extract & Eucheuma cottonii & Cancer-induced rats & $\begin{array}{l}\text { Upregulation of antioxidant enzymes, e.g., CAT, SOD, } \\
\text { and GPx }\end{array}$ & [89] \\
\hline 25 & Methanolic extracts & $\begin{array}{l}\text { Fucus serratus and } F . \\
\text { vesiculosus }\end{array}$ & Caco-2 cells & DNA damage & [106] \\
\hline 26 & Methanolic extracts & Pelvetia canaliculata & Caco-2 cells & Inhibited $\mathrm{H}_{2} \mathrm{O}_{2}$-induced SOD depletion & [106] \\
\hline 27 & Ethanol extracts & C. japonica & Caco- 2 cells & Activating cellular antioxidant enzymes & [63] \\
\hline 28 & Aqueous extract & G. tenuistipitata & H1299 cell line & Activating cellular antioxidant enzymes & [59] \\
\hline
\end{tabular}




\subsection{Anti-Inflammatory Activity of Marine Algal Bioactive Metabolites}

Inflammation is a molecular marker of carcinogenesis. Marine natural products are well-known anti-inflammatory agents due to their potent antioxidant activity. Several anti-inflammatory compounds with potential pharmacological applications have been isolated from marine algal sources. Macroalgae contain several polysaccharides, such as fucoidan, fucans, alginates, laminarin, agar, and carrageenans, which are used as prebiotic compounds and that can have potential application as anti-inflammatory agents. Marinederived carotenoids and astaxanthin exhibit potent anti-inflammatory activity [108,109].

The anti-inflammatory activity of marine algae is due to the presence of PUFAs (e.g., omega-3) that potentiate inhibition of inflammation [27]. Several studies have demonstrated that omega- 3 to 6 fatty acids reduce inflammation when taken as dietary supplements [27]. The polysaccharide extracted from Turbinaria ornate, Delesseria sanguinea exhibited anti-inflammatory potential in several in vitro systems. Sulfated polysaccharide fraction from Gracilaria caudate, a galactan from Gelidium crinale, a mucin-binding agglutinin from Hypnea cervicornis, lectin from Pterocladiella capillacea, and sulfated galactofucan from Lobophora variegata also exhibited anti-inflammatory potency [110]. Oral administration of marine polysaccharide in an in vivo mouse model reduced the initiation of inflammation [111].

The alga Spirulina had demonstrated anti-inflammatory effects when assessed using a non-alcoholic steatohepatitis model [112]. C-phycocyanin from Spirulina platensis blocked inflammation via inhibiting the expressions of nitric oxide synthase, cyclooxygenase-2, and production of pro-inflammatory cytokines [113,114]. Methanolic extracts of Ulva lactuca and $U$. conglobate have shown anti-inflammatory effects in murine hippocampal HT22 cell line [115]. Lycopene from Chlorella marina demonstrated anti-inflammatory effects in an arthritic rat model [116]. Phytosterols from Dunaliella tertiolecta, aqueous and methanolic extracts of Caulerpa mexicana and lectin from Caulerpa cupressoides exhibited antiinflammatory activities in several in vitro models [117]. Ethanolic extract of Ecklonia cava inhibited LPS-induced inflammation in human endothelial cells [118]. Furthermore, Ishige okamurae showed anti-inflammatory effects in a few in vitro models [119]. The astaxanthin isolated from Haematococcus pluvialis reduced gastric inflammation in Helicobacter pyloriinfected mice via decreasing bacterial density [120]. Moreover, astaxanthin reduced the production of pro-inflammatory mediators and cytokines such as nuclear factor- $\mathrm{kB}$ (NF- $\mathrm{kB}$ ), tumor necrosis factor- $\alpha$ (TNF- $\alpha$ ), and interleukin-6 (IL-6), and suppresses T lymphocyte activation in asthma patients [120]. Fucans from Sargassum vulgare, Lobophora variegata, and Spatoglossum schroederi also displayed anti-inflammatory effects [121]. Furthermore, Alginic acid from Sargassum wightii exhibited anti-inflammatory effects in vivo in a rat model [121].

Methanolic extract of Bryothamnion triquetrum exhibited an anti-inflammatory effect in Swiss albino mice [122]. Two fatty acids of Gracilaria verrucosa such as (E)-10-oxooctadec-8enoic acid and (E)-9-oxooctadec-10-enoic acid inhibited the production of inflammatory markers, such as nitric oxide, IL-6, and TNF- $\alpha$ [123]. The sulfoglycolipidic isolated from the red alga Porphyridium cruentum exhibited an anti-inflammatory effect due to the presence of AA (6.8\%), palmitic acid (26.1\%), and EPA (16.6\%), and omega-9 fatty acid (10.5\%) [124]. Pheophytin from Enteromorpha prolifera has superoxide radical $\left(\mathrm{O}_{2}{ }^{-}\right)$reducing potential and inflammatory responses in mice $[125,126]$. A glycoprotein extracted from Porphyra yezoensis exhibited anti-inflammatory effects in LPS-stimulated macrophages [118]. Furthermore, phlorotannins (a polyphenol derived from Eisenia bicyclis, Ecklonia cava, and Ecklonia kurome), and sargachromanol G (derived from Sargassum siliquastrum) showed promising anti-inflammatory activity via inhibition of the production of inflammatory mediators in LPS-stimulated cells $[127,128]$. Moreover, methanolic extract of Neorhodomela aculeata inhibited ROS generation, $\mathrm{H}_{2} \mathrm{O}_{2}$-induced lipid peroxidation, and inducible nitric oxide synthase in neurological diseases via inhibition of inflammation [129].

\subsection{Significance of Marine Algal Bioactive Metabolites as Anti-Diabetes Drugs}

Diabetes mellitus is a chronic metabolic disorder which is characterized by high blood glucose levels that lead to renal dysfunction, cardiovascular diseases, and retinal 
damage [1]. Dietary management is a novel target for treating diabetes via maintaining the correct concentrations of both blood glucose and blood lipids [130]. Commercially available antidiabetic drugs exert several diseases-associated adverse side effects during treatments [131]. In this context, the identification of natural antidiabetic drugs with enhanced drug efficacy and lesser adverse effects has gained the attention of researchers in recent times. Marine algae-derived bioactive compounds exhibited antidiabetic properties furnished by regulation of various signaling pathways, such as inhibitory effect on enzymes such as $\alpha$-amylase, $\alpha$-glucosidase, aldose reductase, dipeptidyl peptidase- 4 , and protein tyrosine phosphatase 1B (PTP 1B) enzyme [132]. Enzymes like $\alpha$-amylase and $\alpha$-glucosidase play a significant role in the digestion of carbohydrates, leading to a delay in glucose absorption in blood and also to a reduction of glucose levels in blood plasma. Subsequently, these compounds may be exploited as potential functional food ingredients for preventing or diminishing insulin resistance and diabetes [132].

Marine algal compounds modulated the GLUT-4 and AMPK signaling pathways and triggered glucose tolerance [1]. Recent investigations displayed that fucoidan act as prebiotics and regulate the intercellular metabolism and blood sugar level [1]. Fucoidan isolated from S. fusiforme controlled the blood glucose level, recovered liver function, and inhibited oxidative stress in STZ-induced diabetic rats [133]. Fucoidan from Ecklonia maxima acted as a potent $\alpha$-glucosidase inhibitor with a very low $\mathrm{IC}_{50}$ value $(0.27-0.31 \mathrm{mg} / \mathrm{mL})$ and regulated type II diabetes [134]. Fucoidan from Fucus vesiculosus displayed a robust $\alpha$-glucosidase inhibitor in diabetes treatment [135]. Furthermore, low molecular weight fucoidan (LMWF) from S. hemiphyllum in combination with fucoxanthin displayed antidiabetic properties in type II diabetes rat model $(\mathrm{db} / \mathrm{db})$. The oral administration of LMWF in combination with fucoxanthin decreased blood glucose and fasting blood sugar levels [135]. The synergistic drug effect was more effective in the in vivo model via reduction of urinal sugar level as compared to the LMWF treatment alone. LMWF enhanced the hepatic glycogen concentration and antioxidant enzymes which were assisted by lipid metabolism. The lipid metabolism displayed the regulation of glucose transporter (GLUT), insulin receptor substrate (IRS-1), peroxisome proliferator-activated receptor-gamma (PPAR $\gamma$ ), and uncoupling protein (UCP)-1 level with the treatment of LMWF in combination with fucoxanthin [135]. Fucoidan from Cucumaria frondosa amplified the expression of insulin receptor substrate 1, Glut-4, and PI3K/Akt, glucose transporter protein in insulin-resistant rats [1]. Fucoidan from Saccarina japonica abridged blood sugar level too [1,136].

Moreover, sulfated fucoidan isolated from Undaria pinnatifida inhibited hyperglycemia by eliciting insulin sensitivity in a diabetic mouse (C57BL/KSJ/db/db) model [137]. Fucoidan from Sargassum wightii inhibited alpha-D-glucosidase that transport glucose into the blood and reduce glucose level in blood [138]. Dieckol, fucodiphloroethol G, 6,6'-Bieckol, 7phloroeckol, phlorofucofuroeckol A from E. cava and phloroglucinol, dioxinodehydroeckol, eckol from E. stolonifera and E. bicyclis displayed robust $\alpha$-glucosidase activity and reduced blood sugar level [139-141]. Furthermore, dieckol-rich extract from E. cava improved insulin sensitivity [142]. Polyphenolic-rich extract from I. okamurae improved insulin sensitivity [143]. Moreover, polyphenolic-rich extract from E. cava inhibited glucose uptake effect in skeletal muscle [141]. Fucosterol from Pelvetia siliquosa reduced serum glucose concentration and inhibited sorbitol accumulation in the lenses in Sprague-Dawley diabetic rats [144]. Phlorotannin components from Ascophyllum nodosum displayed potential inhibition of $\alpha$-amylase and $\alpha$-glucosidase activities in in vitro models [145]. Sodium alginate from Laminaria angustata inhibited the rising blood glucose and insulin levels in Wistar rats [146]. Fucoxanthin and fucosterol from Undaria pinnatifida and Ecklonia stolonifera displayed aldose reductase inhibition $[147,148]$. Furthermore, pheophorbide-A, pheophytin-A also displayed aldose reductase inhibition [149]. Algal bioactive metabolites and their functional role in diabetes are summarized in Table 2. 
Table 2. Marine algal bioactive metabolites and their functional role in diabetes.

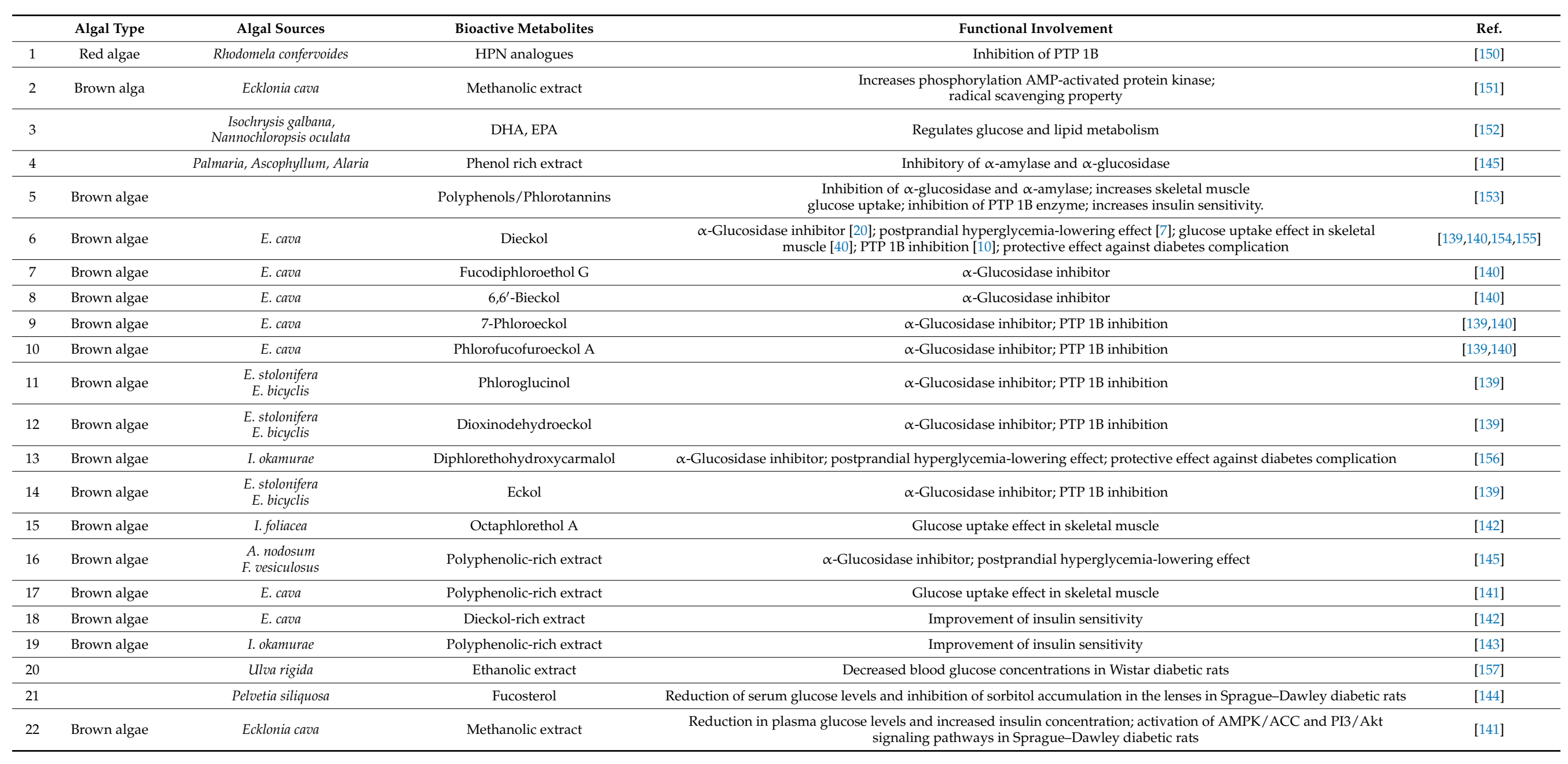


Table 2. Cont.

\begin{tabular}{|c|c|c|c|c|c|}
\hline & Algal Type & Algal Sources & Bioactive Metabolites & Functional Involvement & Ref. \\
\hline 23 & $\begin{array}{l}\text { Green algae } \\
\text { and Diatoms }\end{array}$ & Chlorella sp., Nitzschia laevis & Microalgal extracts & Inhibition of advanced glycation endproducts (AGEs) formation in in vitro models & [158] \\
\hline 24 & Brown algae & Ascophyllum nodosum & Phlorotannin components & Inhibition of $\alpha$-amylase and $\alpha$-glucosidase activities in vitro & [145] \\
\hline 26 & Brown algae & Eisenia bicyclis & Dioxinodehydroeckol & $\alpha$-Glucosidase inhibitor & [159] \\
\hline 27 & Brown algae & Eisenia bicyclis & 7-Phloroeckol & PTP 1B inhibition; $\alpha$-glucosidase inhibitor & [159] \\
\hline 28 & Brown algae & Eisenia bicyclis & Fucoxanthin & Aldose reductase inhibition & [148] \\
\hline 29 & Brown algae & Ecklonia cava & Dieckol & $\alpha$-Glucosidase inhibitor & [160] \\
\hline 30 & Brown algae & Ecklonia cava & Fucodiphloroethol G & $\alpha$-Amylase inhibitor & [160] \\
\hline 31 & Brown algae & Ecklonia cava & 6,6'-Bieckol & PTP 1B inhibition & [160] \\
\hline 32 & Brown algae & Ecklonia cava & 7-Phloroeckol & ACE inhibitor & [160] \\
\hline 33 & Brown algae & Ecklonia cava & 2-Phloroeckol & $\begin{array}{c}\alpha \text {-Glucosidase inhibitor; } \alpha \text {-glucosidase inhibitor; } \alpha \text {-glucosidase inhibitor; PTP 1B inhibition; } \\
\text { aldose reductase inhibition; } \\
\text { aldose reductase inhibition }\end{array}$ & {$[139,161]$} \\
\hline 34 & Brown algae & Ecklonia cava & Phlorofucofuroeckol A & $\alpha$-glucosidase inhibitor; PTP 1B inhibition; ACE inhibitor; AGEs inhibition; Aldose reductase inhibition & {$[139,162]$} \\
\hline 35 & Brown algae & Ecklonia stolonifera & Phloroglucinol & $\alpha$-glucosidase inhibitor & [153] \\
\hline 36 & Brown algae & Ecklonia stolonifera & Eckol & PTP 1B inhibition $\alpha$-glucosidase inhibitor & [153] \\
\hline 38 & Brown algae & Ecklonia stolonifera & Phlorofucofuroeckol A & $\begin{array}{l}\alpha \text {-Amylase inhibitor; PTP 1B inhibition; } \\
\text { ACE inhibitor; } \alpha \text {-glucosidase inhibitor }\end{array}$ & {$[144,160]$} \\
\hline 39 & Brown algae & Ecklonia stolonifera & Fucosterol & PTP 1B inhibition; aldose reductase inhibition & [147] \\
\hline 40 & Brown algae & Ishige okamurae & Diphlorethohydroxycarmalol & $\alpha$-Glucosidase inhibitor; $\alpha$-amylase inhibitor & [163] \\
\hline 41 & Brown algae & Myagropsis myagroides & Eckol & $\alpha$-Glucosidase inhibitor; $\alpha$-amylase inhibitor & [153] \\
\hline 42 & Brown algae & Sargassum serratifolium & Sargahydroquinoic acid & ACE inhibitor; PTP 1B inhibition & [164] \\
\hline 43 & Brown algae & Ascophyllum nodosum & Methanol extract & $\alpha$-Glucosidase inhibitor; $\alpha$-amylase inhibitor & [145] \\
\hline 44 & Brown algae & Saccharina japonica & Pheophorbide-A & Aldose reductase inhibition & [149] \\
\hline 45 & Brown algae & Saccharina japonica & Pheophytin-A & Aldose reductase inhibition & [149] \\
\hline 46 & Brown algae & Undaria pinnatifida & Fucoxanthin & Aldose reductase inhibition & [148] \\
\hline
\end{tabular}




\section{Algal Metabolites as Prebiotics for Human Health with Special References to Fucoidan}

Algal metabolite consumption, such as polysaccharides, sulfated polysaccharides, fucoidans, chlorophylls, phycobilins, fucoxanthins, carotenoids, polyphenols, and omega-3 fatty acids, decreases blood pressure and sugar level, and it can have antiviral, antiinflammatory, anticancer, and neuroprotective effects, as well as act as immune boost-up. The immunomodulatory potential of prebiotics modulates immune fitness via several metabolic processes and interactions with the gut microbiota in humans [165]. The gut microbiota produces short-chain fatty acids (SCFA) such as propionate, acetate and butyrate by breaking down prebiotics and modulating the immune response [165]. Intravenous use of acetate amplified the activity of NK cells in cancer patients. In addition, it activated G protein-coupled receptors (GPR41 and GPR43) in rats, thus triggering mitogen-activated protein kinase (MAPK) signaling and modulating the transcription factors activity [166]. Acetate also increased the production of IL-10 in rats and prevented the inhibitory activity of butyrate on IL-2 production [167]. Daily administration of fucoidans from A. nodosum increased in Lactobacillus and Ruminococcus in the intestine of mice [168].

Fucoidan possesses a wide range of immune-modulation effects by stimulating activation of natural killer (NK) cells, dendritic cells (DCs), and T cells and increasing anti-tumor and anti-viral responses [169]. Fucoidan enhanced immune modulation via activation of macrophage facilitated by membrane receptors, such as TLR4, cluster of differentiation 14 (CD14), competent receptor-3 (CR-3), and scavenging receptor (SR). This led to signal transduction via MAPK and activation of transcription factors, and it also induced cytokines production, which regulates activation of NK cells and T lymphocytes [170]. In this regard, treatment of C57BL/ 6 rats with fucoidan extracted from Fucus vesiculosus upregulated pro-inflammatory cytokines (IL-6, IL-12, and TNF- $\alpha$ ) in serum and spleenocytes after $3 \mathrm{~h}$ of administration [171]. Furthermore, fucoidan from L. cichorioides, L. Japonica, and F. evanescens served as TLR ligands and their interaction with TLR-2 and TLR-4 receptors in vitro activated NF-jB. Furthermore, it also controlled the expression of the defense mechanisms of intrinsic immunity, such as secretion of chemokines, cytokines, and manifestation of MHC class I and II particles [1]. These are essential for the defense against foreign attackers and for activating adaptive immune systems. A clinical trial based on the diet supplementation of $1 \mathrm{~g} /$ day of fucoidan from Undaria pinnatifida on adult male and female volunteers for 24 weeks showed modulation of the immunity to seasonal influenza vaccine by antibody production [172]. Based on these reports, there are several evidences that fucoidan acts as a potent prebiotic and that it is able to modulate immunity. This is achieved by interacting with intestinal cells of the gut microbiota and direct motivation of immune cells through TLRs.

\section{Conclusions and Future Perspectives}

Natural extracts have been used since ancient times for treating various illnesses. Products from natural products have also provided a large number of pharmaceuticals, or their prototypes, in recent times. Among the many natural sources, marine algae can still play a pivotal role in human health and disease because of the need for novel drug candidates. Their extracts are already well-known in traditional medicine and more recent studies investigated the many beneficial effects of their secondary metabolites, such as reduction of oxidative stress and modulation of apoptosis, and the main findings of these researches are summarized in this review. The exploitation of these results might lead to the development of novel algal dietary supplements and pharmaceuticals for preventing and treating chronic malfunctions and other age-associated chronic diseases. For example, sulfated fucoidans have been shown to be potential candidates as new pharmaceuticals in fighting cancer and diabetes. However, despite the extensive use of algae-derived compounds and extracts in the food industry, there are still no FDA-approved anticancer, antioxidant, anti-inflammatory, and antidiabetic drugs. Technology transfer from the preclinical results to the clinical application of secondary metabolites extracted from marine 
algae is still in its infancy and not fully exploited and more clinical studies are needed to really evaluate the pharmaceutical efficacy algal compounds.

In conclusion, marine algae offer a great variety of bioactive molecules with potential health benefits. Several types of marine algae are already consumed as food additives and nutritional supplements, potentially exerting their beneficial effects through diet. There is, however, an impelling necessity of considering the algal bioactive compounds in new drug discovery programs and to investigate their biological effects in deeper detail in order to find new pharmaceuticals with preventive and therapeutic efficacy.

Author Contributions: Writing-original draft preparation, B.P., R.N., and S.P.; visualization, B.P. and B.P.J.; review and editing, A.R. and M.J. All authors have read and agreed to the published version of the manuscript.

Funding: This research was partially funded by "Tecnopolo per la medicina di precisione" (TecnoMed Puglia)—Regione Puglia: DGR n.2117 del 21/11/2018, CUP: B84I18000540002 and "Tecnopolo di Nanotecnologia e Fotonica per la medicina di precisione" (TECNOMED)_FISR/MIUR-CNR: delibera CIPE n.3449 del 7-08-2017, CUP: B83B17000010001.

Acknowledgments: The authors are thankful to Berhampur University for providing the necessary facilities to carry out this work. We are also thankful to Pradyot Kumar Behera for helping to draw the molecular structure of algal metabolites.

Conflicts of Interest: The authors declare no conflict of interest.

\section{References}

1. Pradhan, B.; Patra, S.; Nayak, R.; Behera, C.; Dash, S.R.; Nayak, S.; Sahu, B.B.; Bhutia, S.K.; Jena, M. Multifunctional role of fucoidan, sulfated polysaccharides in human health and disease: A journey under the sea in pursuit of potent therapeutic agents. Int. J. Biol. Macromol. 2020, 164, 4263-4278. [CrossRef] [PubMed]

2. World Health Organization. Global Status Report on Alcohol and Health 2018; World Health Organization: Geneve, Switzerland, 2018.

3. Balakumar, P.; Maung-U, K.; Jagadeesh, G. Prevalence and prevention of cardiovascular disease and diabetes mellitus. Pharmacol. Res. 2016, 113, 600-609. [CrossRef] [PubMed]

4. Adeloye, D.; Ige, J.O.; Aderemi, A.V.; Adeleye, N.; Amoo, E.O.; Auta, A.; Oni, G. Estimating the prevalence, hospitalisation and mortality from type 2 diabetes mellitus in Nigeria: A systematic review and meta-analysis. BMJ Open 2017, 7, e015424. [CrossRef]

5. Niemeijer, M.N.; van den Berg, M.E.; Leening, M.J.; Hofman, A.; Franco, O.H.; Deckers, J.W.; Heeringa, J.; Rijnbeek, P.R.; Stricker, B.H.; Eijgelsheim, M. Declining incidence of sudden cardiac death from 1990-2010 in a general middle-aged and elderly population: The Rotterdam Study. Heart Rhythm 2015, 12, 123-129. [CrossRef]

6. Wepner, B.; Giesecke, S. Drivers, trends and scenarios for the future of health in Europe. Impressions from the FRESHER project. Eur. J. Futures Res. 2018, 6, 2. [CrossRef]

7. Azab, A.; Nassar, A.; Azab, A.N. Anti-Inflammatory Activity of Natural Products. Molecules 2016, 21, 1321. [CrossRef] [PubMed]

8. Ragusa, A.; Centonze, C.; Grasso, M.E.; Latronico, M.F.; Mastrangelo, P.F.; Fanizzi, F.P.; Maffia, M. Composition and Statistical Analysis of Biophenols in Apulian Italian EVOOs. Foods 2017, 6, 90. [CrossRef]

9. Ragusa, A.; Centonze, C.; Grasso, M.E.; Latronico, M.F.; Mastrangelo, P.F.; Sparascio, F.; Fanizzi, F.P.; Maffia, M. A Comparative Study of Phenols in Apulian Italian Wines. Foods 2017, 6, 24. [CrossRef]

10. Ragusa, A.; Centonze, C.; Grasso, M.E.; Latronico, M.F.; Mastrangelo, P.F.; Sparascio, F.; Maffia, M. HPLC Analysis of Phenols in Negroamaro and Primitivo Red Wines from Salento. Foods 2019, 8, 45. [CrossRef]

11. Zafar, M.S.; Quarta, A.; Marradi, M.; Ragusa, A. Recent Developments in the Reduction of Oxidative Stress through Antioxidant Polymeric Formulations. Pharmaceutics 2019, 11, 505. [CrossRef]

12. Patra, S.; Praharaj, P.P.; Panigrahi, D.P.; Panda, B.; Bhol, C.S.; Mahapatra, K.K.; Mishra, S.R.; Behera, B.P.; Jena, M.; Sethi, G.; et al. Bioactive compounds from marine invertebrates as potent anticancer drugs: The possible pharmacophores modulating cell death pathways. Mol. Biol. Rep. 2020, 47, 7209-7228. [CrossRef] [PubMed]

13. Maharana, S.; Pradhan, B.; Jena, M.; Misra, M.K. Diversity of Phytoplankton in Chilika Lagoon, Odisha, India. Environ. Ecol. 2019, 37, 737-746.

14. Suleria, H.A.R.; Osborne, S.; Masci, P.; Gobe, G. Marine-based nutraceuticals: An innovative trend in the food and supplement industries. Mar. Drugs 2015, 13, 6336-6351. [CrossRef] [PubMed]

15. Tanna, B.; Mishra, A. Metabolites unravel nutraceutical potential of edible seaweeds: An emerging source of functional food. Compr. Rev. Food Sci. Food Saf. 2018, 17, 1613-1624. [CrossRef] [PubMed]

16. Mohanty, S.; Pradhan, B.; Patra, S.; Behera, C.; Nayak, R.; Jena, M. Screening for nutritive bioactive compounds in some algal strains isolated from coastal Odisha. J. Adv. Plant Sci. 2020, 10, 1-8. 
17. Miranda, J.M.; Trigo, M.; Barros-Velázquez, J.; Aubourg, S.P. Effect of an icing medium containing the alga Fucus spiralis on the microbiological activity and lipid oxidation in chilled megrim (Lepidorhombus whiffiagonis). Food Control 2016, 59, $290-297$. [CrossRef]

18. Barros-Velázquez, J.; Miranda, J.M.; Ezquerra-Brauer, J.M.; Aubourg, S.P. Impact of icing systems with aqueous, ethanolic and ethanolic-aqueous extracts of alga Fucus spiralis on microbial and biochemical quality of chilled hake (Merluccius merluccius). Int. J. Food Sci. Technol. 2016, 51, 2081-2089. [CrossRef]

19. Conlon, M.A.; Bird, A.R. The impact of diet and lifestyle on gut microbiota and human health. Nutrients 2015, 7, 17-44. [CrossRef]

20. Patra, S.; Pradhan, B.; Nayak, R.; Behera, C.; Rout, L.; Jena, M.; Efferth, T.; Bhutia, S.K. Chemotherapeutic efficacy of curcumin and resveratrol against cancer: Chemoprevention, chemoprotection, drug synergism and clinical pharmacokinetics. Semin. Cancer Biol. 2020. [CrossRef]

21. Ibañez, E.; Herrero, M.; Mendiola, J.A.; Castro-Puyana, M. Extraction and characterization of bioactive compounds with health benefits from marine resources: Macro and micro algae, cyanobacteria, and invertebrates. In Marine Bioactive Compounds; Springer: Boston, MA, USA, 2012; pp. 55-98.

22. Lordan, S.; Ross, R.P.; Stanton, C. Marine bioactives as functional food ingredients: Potential to reduce the incidence of chronic diseases. Mar. Drugs 2011, 9, 1056-1100. [CrossRef]

23. Bocanegra, A.; Bastida, S.; Benedí, J.; Rodenas, S.; Sanchez-Muniz, F.J. Characteristics and nutritional and cardiovascular-health properties of seaweeds. J. Med. Food 2009, 12, 236-258. [CrossRef] [PubMed]

24. Taboada, C.; Millán, R.; Míguez, I. Composition, nutritional aspects and effect on serum parameters of marine algae Ulva rigida. J. Sci. Food Agric. 2010, 90, 445-449. [PubMed]

25. Ruxton, C.; Reed, S.C.; Simpson, M.; Millington, K. The health benefits of omega-3 polyunsaturated fatty acids: A review of the evidence. J. Hum. Nutr. Diet. 2004, 17, 449-459. [CrossRef] [PubMed]

26. Zheng, J.-S.; Hu, X.-J.; Zhao, Y.-M.; Yang, J.; Li, D. Intake of fish and marine n-3 polyunsaturated fatty acids and risk of breast cancer: Meta-analysis of data from 21 independent prospective cohort studies. BMJ 2013, 346, f3706. [CrossRef] [PubMed]

27. Wall, R.; Ross, R.P.; Fitzgerald, G.F.; Stanton, C. Fatty acids from fish: The anti-inflammatory potential of long-chain omega-3 fatty acids. Nutr. Rev. 2010, 68, 280-289. [CrossRef]

28. Fleurence, J.; Gutbier, G.; Mabeau, S.; Leray, C. Fatty acids from 11 marine macroalgae of the French Brittany coast. J. Appl. Phycol. 1994, 6, 527-532. [CrossRef]

29. Sánchez-Machado, D.; López-Cervantes, J.; Lopez-Hernandez, J.; Paseiro-Losada, P. Fatty acids, total lipid, protein and ash contents of processed edible seaweeds. Food Chem. 2004, 85, 439-444. [CrossRef]

30. Rodríguez-Meizoso, I.; Jaime, L.; Santoyo, S.; Señoráns, F.J.; Cifuentes, A.; Ibáñez, E. Subcritical water extraction and characterization of bioactive compounds from Haematococcus pluvialis microalga. J. Pharm. Biomed. Anal. 2010, 51, 456-463. [CrossRef]

31. Bouzidi, N.; Viano, Y.; Ortalo-Magne, A.; Seridi, H.; Alliche, Z.; Daghbouche, Y.; Culioli, G.; El Hattab, M. Sterols from the brown alga Cystoseira foeniculacea: Degradation of fucosterol into saringosterol epimers. Arab. J. Chem. 2019, 12, 1474-1478. [CrossRef]

32. Menshova, R.V.; Ermakova, S.P.; Anastyuk, S.D.; Isakov, V.V.; Dubrovskaya, Y.V.; Kusaykin, M.I.; Um, B.-H.; Zvyagintseva, T.N. Structure, enzymatic transformation and anticancer activity of branched high molecular weight laminaran from brown alga Eisenia bicyclis. Carbohydr. Polym. 2014, 99, 101-109. [CrossRef]

33. Pereira, L.; Bahcevandziev, K.; Joshi, N.H. Seaweeds as Plant Fertilizer, Agricultural Biostimulants and Animal Fodder; CRC Press: Boca Raton, FL, USA, 2019.

34. Mohamed, S.; Hashim, S.N.; Rahman, H.A. Seaweeds: A sustainable functional food for complementary and alternative therapy. Trends Food Sci. Technol. 2012, 23, 83-96. [CrossRef]

35. Lahaye, M. Marine algae as sources of fibres: Determination of soluble and insoluble dietary fibre contents in some 'sea vegetables'. J. Sci. Food Agric. 1991, 54, 587-594. [CrossRef]

36. Mišurcová, L.; Škrovánková, S.; Samek, D.; Ambrožová, J.; Machů, L. Health benefits of algal polysaccharides in human nutrition. In Advances in Food and Nutrition Research; Elsevier: Amsterdam, The Netherlands, 2012; Volume 66, pp. 75-145.

37. Jiménez-Escrig, A.; Sánchez-Muniz, F. Dietary fibre from edible seaweeds: Chemical structure, physicochemical properties and effects on cholesterol metabolism. Nutr. Res. 2000, 20, 585-598. [CrossRef]

38. Wijesinghe, W.; Jeon, Y.-J. Biological activities and potential industrial applications of fucose rich sulfated polysaccharides and fucoidans isolated from brown seaweeds: A review. Carbohydr. Polym. 2012, 88, 13-20. [CrossRef]

39. Becker, W. Microalgae in human and animal nutrition. In Handbook of Microalgal Culture: Biotechnology and Applied Phycology; Richmond, A., Ed.; Wiley Online Library: Hoboken, NJ, USA, 2004; pp. 312-351.

40. Pugh, N.; Ross, S.A.; ElSohly, H.N.; ElSohly, M.A.; Pasco, D.S. Isolation of three high molecular weight polysaccharide preparations with potent immunostimulatory activity from Spirulina platensis, Aphanizomenon flos-aquae and Chlorella pyrenoidosa. Planta Med. 2001, 67, 737-742. [CrossRef]

41. Shao, B.; Wang, Z.; Liu, X.; Yu, J.; Lan, J.; Wang, J.; Ma, L.; Chen, Z. Breeding of a Chlorella strain with high yield of polysaccharide and its effect on growth and immunoregulation of Litopenaeus vannamei. J. Nucl. Agric. Sci. 2013, 27, 168-172.

42. Bravo, L. Polyphenols: Chemistry, dietary sources, metabolism, and nutritional significance. Nutr. Rev. 1998, 56, 317-333. [CrossRef] 
43. Fernando, I.S.; Kim, M.; Son, K.-T.; Jeong, Y.; Jeon, Y.-J. Antioxidant activity of marine algal polyphenolic compounds: A mechanistic approach. J. Med. Food 2016, 19, 615-628. [CrossRef]

44. Faulks, R.M.; Southon, S. Challenges to understanding and measuring carotenoid bioavailability. Biochim. Biophys. Acta (BBA) Mol. Basis Dis. 2005, 1740, 95-100. [CrossRef]

45. Matos, J.; Cardoso, C.; Bandarra, N.; Afonso, C. Microalgae as healthy ingredients for functional food: A review. Food Funct. 2017, 8, 2672-2685. [CrossRef]

46. Kim, S.-K.; Taylor, S. Marine Medicinal Foods: Implications and Applications, Macro and Microalgae; Academic Press: Cambridge, MA, USA, 2011; Volume 64.

47. Circuncisão, A.R.; Catarino, M.D.; Cardoso, S.M.; Silva, A. Minerals from macroalgae origin: Health benefits and risks for consumers. Mar. Drugs 2018, 16, 400. [CrossRef]

48. Rupérez, P. Mineral content of edible marine seaweeds. Food Chem. 2002, 79, 23-26. [CrossRef]

49. Kini, S.; Divyashree, M.; Mani, M.K.; Mamatha, B.S. Algae and cyanobacteria as a source of novel bioactive compounds for biomedical applications. In Advances in Cyanobacterial Biology; Elsevier: Amsterdam, The Netherlands, 2020 ; pp. 173-194.

50. Shahidi, F. Functional foods: Their role in health promotion and disease prevention. J. Food Sci. 2004, 69, R146-R149. [CrossRef]

51. Sharma, N.; Khanra, A.; Rai, M.P. Potential applications of antioxidants from algae in human health. In Oxidative Stress: Diagnostic Methods and Applications in Medical Science; Springer: Berlin, Germany, 2017; pp. 153-168.

52. Bayr, H. Reactive oxygen species. Crit. Care Med. 2005, 33, S498-S501. [CrossRef] [PubMed]

53. Halliwell, B. Free radicals and other reactive species in disease. eLS 2001. [CrossRef]

54. Storz, P. Reactive oxygen species in tumor progression. Front. Biosci. 2005, 10, 1881-1896. [CrossRef] [PubMed]

55. Halliwell, B. Reactive species and antioxidants. Redox biology is a fundamental theme of aerobic life. Plant Physiol. 2006, 141, 312-322. [CrossRef]

56. Gechev, T.S.; Van Breusegem, F.; Stone, J.M.; Denev, I.; Laloi, C. Reactive oxygen species as signals that modulate plant stress responses and programmed cell death. Bioessays 2006, 28, 1091-1101. [CrossRef]

57. Ribeiro, J.S.; Santos, M.J.M.C.; Silva, L.K.R.; Pereira, L.C.L.; Santos, I.A.; da Silva Lannes, S.C.; da Silva, M.V. Natural antioxidants used in meat products: A brief review. Meat Sci. 2019, 148, 181-188. [CrossRef]

58. Estrada, J.P.; Bescós, P.B.; Del Fresno, A.V. Antioxidant activity of different fractions of Spirulina platensis protean extract. IL Farmaco 2001, 56, 497-500. [CrossRef]

59. Chakraborty, K.; Paulraj, R. Sesquiterpenoids with free-radical-scavenging properties from marine macroalga Ulva fasciata Delile. Food Chem. 2010, 122, 31-41. [CrossRef]

60. Meenakshi, S.; Gnanambigai, D.M.; Mozhi, S.T.; Arumugam, M.; Balasubramanian, T. Total flavanoid and in vitro antioxidant activity of two seaweeds of Rameshwaram coast. Glob. J. Pharm. 2009, 3, 59-62.

61. Balaji Raghavendra Rao, H.; Sathivel, A.; Devaki, T. Antihepatotoxic nature of Ulva reticulata (Chlorophyceae) on acetaminopheninduced hepatoxicity in experimental rats. J. Med. Food 2004, 7, 495-497. [CrossRef] [PubMed]

62. Shibata, T.; Ishimaru, K.; Kawaguchi, S.; Yoshikawa, H.; Hama, Y. Antioxidant activities of phlorotannins isolated from Japanese Laminariaceae. In Proceedings of the Nineteenth International Seaweed Symposium, Kobe, Japan, 26-31 March 2007; Borowitzka, M.A., Critchley, A.T., Kraan, S., Peters, A., Sjøtun, K., Notoya, M., Eds.; Springer: Amsterdam, The Netherlands, 2009 ; pp. $255-261$.

63. Kang, K.A.; Bu, H.D.; Park, D.S.; Go, G.M.; Jee, Y.; Shin, T.; Hyun, J.W. Antioxidant activity of ethanol extract of Callophyllis japonica. Phytother. Res. 2005, 19, 506-510. [CrossRef] [PubMed]

64. Yang, J.-I.; Yeh, C.-C.; Lee, J.-C.; Yi, S.-C.; Huang, H.-W.; Tseng, C.-N.; Chang, H.-W. Aqueous extracts of the edible Gracilaria tenuistipitata are protective against $\mathrm{H} 2 \mathrm{O} 2$-induced DNA damage, growth inhibition, and cell cycle arrest. Molecules 2012, 17, 7241-7254. [CrossRef]

65. Avendaño, C.; Menendez, J.C. Medicinal Chemistry of Anticancer Drugs; Elsevier: Amsterdam, The Netherlands, 2015.

66. Kalimuthu, S.; Se-Kwon, K. Cell survival and apoptosis signaling as therapeutic target for cancer: Marine bioactive compounds. Int. J. Mol. Sci. 2013, 14, 2334-2354. [CrossRef]

67. Pradhan, B.; Patra, S.; Behera, C.; Nayak, R.; Patil, S.; Bhutia, S.K.; Jena, M. Enteromorpha compressa extract induces anticancer activity through apoptosis and autophagy in oral cancer. Mol. Biol. Rep. 2020. [CrossRef]

68. Talero, E.; García-Mauriño, S.; Ávila-Román, J.; Rodríguez-Luna, A.; Alcaide, A.; Motilva, V. Bioactive compounds isolated from microalgae in chronic inflammation and cancer. Mar. Drugs 2015, 13, 6152-6209. [CrossRef]

69. Dore, C.M.P.G.; Alves, M.G.C.F.; Santos, N.D.; Cruz, A.K.M.; Câmara, R.B.G.; Castro, A.J.G.; Alves, L.G.; Nader, H.B.; Leite, E.L. Antiangiogenic activity and direct antitumor effect from a sulfated polysaccharide isolated from seaweed. Microvasc. Res. 2013, 88, 12-18. [CrossRef]

70. Kang, Y.; Wang, Z.-J.; Xie, D.; Sun, X.; Yang, W.; Zhao, X.; Xu, N. Characterization and potential antitumor activity of polysaccharide from Gracilariopsis lemaneiformis. Mar. Drugs 2017, 15, 100. [CrossRef]

71. Ropellato, J.; Carvalho, M.M.; Ferreira, L.G.; Noseda, M.D.; Zuconelli, C.R.; Gonçalves, A.G.; Ducatti, D.R.; Kenski, J.C.; Nasato, P.L.; Winnischofer, S.M. Sulfated heterorhamnans from the green seaweed Gayralia oxysperma: Partial depolymerization, chemical structure and antitumor activity. Carbohydr. Polym. 2015, 117, 476-485. [CrossRef] [PubMed]

72. Synytsya, A.; Kim, W.-J.; Kim, S.-M.; Pohl, R.; Synytsya, A.; Kvasnička, F.; Čopíková, J.; Park, Y.I. Structure and antitumour activity of fucoidan isolated from sporophyll of Korean brown seaweed Undaria pinnatifida. Carbohydr. Polym. 2010, 81, 41-48. [CrossRef] 
73. Rui, X.; Pan, H.-F.; Shao, S.-L.; Xu, X.-M. Anti-tumor and anti-angiogenic effects of Fucoidan on prostate cancer: Possible JAK-STAT3 pathway. BMC Complement. Altern. Med. 2017, 17, 378. [CrossRef] [PubMed]

74. Park, H.Y.; Park, S.-H.; Jeong, J.-W.; Yoon, D.; Han, M.H.; Lee, D.-S.; Choi, G.; Yim, M.-J.; Lee, J.M.; Kim, D.-H. Induction of p53-independent apoptosis and G1 cell cycle arrest by fucoidan in HCT116 human colorectal carcinoma cells. Mar. Drugs 2017, 15, 154. [CrossRef] [PubMed]

75. Suganya, A.M.; Sanjivkumar, M.; Chandran, M.N.; Palavesam, A.; Immanuel, G. Pharmacological importance of sulphated polysaccharide carrageenan from red seaweed Kappaphycus alvarezii in comparison with commercial carrageenan. Biomed. Pharmacother. 2016, 84, 1300-1312. [CrossRef]

76. Kong, C.-S.; Kim, J.-A.; Yoon, N.-Y.; Kim, S.-K. Induction of apoptosis by phloroglucinol derivative from Ecklonia cava in MCF-7 human breast cancer cells. Food Chem. Toxicol. 2009, 47, 1653-1658. [CrossRef]

77. Corona, G.; Coman, M.; Spencer, J.; Rowland, I. Digested and fermented seaweed phlorotannins reduce DNA damage and inhibit growth of HT-29 colon cancer cells. Proc. Nutr. Soc. 2014, 73, E31. [CrossRef]

78. Antunes, E.M.; Afolayan, A.F.; Chiwakata, M.T.; Fakee, J.; Knott, M.G.; Whibley, C.E.; Hendricks, D.T.; Bolton, J.J.; Beukes, D.R. Identification and in vitro anti-esophageal cancer activity of a series of halogenated monoterpenes isolated from the South African seaweeds Plocamium suhrii and Plocamium cornutum. Phytochemistry 2011, 72, 769-772. [CrossRef]

79. Hosokawa, M.; Kudo, M.; Maeda, H.; Kohno, H.; Tanaka, T.; Miyashita, K. Fucoxanthin induces apoptosis and enhances the antiproliferative effect of the PPAR $\gamma$ ligand, troglitazone, on colon cancer cells. Biochim. Biophys. Acta (BBA) Gen. Subj. 2004, 1675, 113-119. [CrossRef]

80. Ishikawa, C.; Tafuku, S.; Kadekaru, T.; Sawada, S.; Tomita, M.; Okudaira, T.; Nakazato, T.; Toda, T.; Uchihara, J.N.; Taira, N. Antiadult T-cell leukemia effects of brown algae fucoxanthin and its deacetylated product, fucoxanthinol. Int. J. Cancer 2008, 123, 2702-2712. [CrossRef]

81. Terasaki, M.; Maeda, H.; Miyashita, K.; Tanaka, T.; Miyamoto, S.; Mutoh, M. A marine bio-functional lipid, fucoxanthinol, attenuates human colorectal cancer stem-like cell tumorigenicity and sphere formation. J. Clin. Biochem. Nutr. 2017, 16-112. [CrossRef]

82. Lakshmi, T.P.; Vajravijayan, S.; Moumita, M.; Sakthivel, N.; Gunasekaran, K.; Krishna, R. A novel guaiane sesquiterpene derivative, guai-2-en-10 $\alpha$-ol, from Ulva fasciata Delile inhibits EGFR/PI3K/Akt signaling and induces cytotoxicity in triple-negative breast cancer cells. Mol. Cell. Biochem. 2018, 438, 123-139. [CrossRef]

83. Lee, J.-C.; Hou, M.-F.; Huang, H.-W.; Chang, F.-R.; Yeh, C.-C.; Tang, J.-Y.; Chang, H.-W. Marine algal natural products with anti-oxidative, anti-inflammatory, and anti-cancer properties. Cancer Cell Int. 2013, 13, 1-7. [CrossRef]

84. Zandi, K.; Tajbakhsh, S.; Nabipour, I.; Rastian, Z.; Yousefi, F.; Sharafian, S.; Sartavi, K. In vitro antitumor activity of Gracilaria corticata (a red alga) against Jurkat and molt-4 human cancer cell lines. Afr. J. Biotechnol. 2010, 9, 6787-6790.

85. Zandi, K.; Ahmadzadeh, S.; Tajbakhsh, S.; Rastian, Z.; Yousefi, F.; Farshadpour, F.; Sartavi, K. Anticancer activity of Sargassum oligocystum water extract against human cancer cell lines. Eur. Rev. Med Pharmacol. Sci. 2010, 14, 669-673.

86. Yeh, C.-C.; Tseng, C.-N.; Yang, J.-I.; Huang, H.-W.; Fang, Y.; Tang, J.-Y.; Chang, F.-R.; Chang, H.-W. Antiproliferation and induction of apoptosis in Ca9-22 oral cancer cells by ethanolic extract of Gracilaria tenuistipitata. Molecules 2012, 17, 10916-10927. [CrossRef]

87. Yeh, C.-C.; Yang, J.-I.; Lee, J.-C.; Tseng, C.-N.; Chan, Y.-C.; Hseu, Y.-C.; Tang, J.-Y.; Chuang, L.-Y.; Huang, H.-W.; Chang, F.-R. Anti-proliferative effect of methanolic extract of Gracilaria tenuistipitata on oral cancer cells involves apoptosis, DNA damage, and oxidative stress. BMC Complement. Altern. Med. 2012, 12, 142. [CrossRef]

88. Kim, J.-Y.; Yoon, M.-Y.; Cha, M.-R.; Hwang, J.-H.; Park, E.; Choi, S.-U.; Park, H.-R.; Hwang, Y.-I. Methanolic extracts of Plocamium telfairiae induce cytotoxicity and caspase-dependent apoptosis in HT-29 human colon carcinoma cells. J. Med. Food 2007, 10, 587-593. [CrossRef]

89. Namvar, F.; Mohamed, S.; Fard, S.G.; Behravan, J.; Mustapha, N.M.; Alitheen, N.B.M.; Othman, F. Polyphenol-rich seaweed (Eucheuma cottonii) extract suppresses breast tumour via hormone modulation and apoptosis induction. Food Chem. 2012, 130, 376-382. [CrossRef]

90. Kim, K.-N.; Ahn, G.; Heo, S.-J.; Kang, S.-M.; Kang, M.-C.; Yang, H.-M.; Kim, D.; Roh, S.W.; Kim, S.-K.; Jeon, B.-T. Inhibition of tumor growth in vitro and in vivo by fucoxanthin against melanoma B16F10 cells. Environ. Toxicol. Pharmacol. 2013, 35, 39-46. [CrossRef]

91. Das, S.K.; Hashimoto, T.; Shimizu, K.; Yoshida, T.; Sakai, T.; Sowa, Y.; Komoto, A.; Kanazawa, K. Fucoxanthin induces cell cycle arrest at G0/G1 phase in human colon carcinoma cells through up-regulation of p21WAF1/Cip1. Biochim. Biophys. Acta (BBA) Gen. Subj. 2005, 1726, 328-335. [CrossRef] [PubMed]

92. Satomi, Y. Fucoxanthin induces GADD45A expression and G1 arrest with SAPK/JNK activation in LNCap human prostate cancer cells. Anticancer Res. 2012, 32, 807-813. [PubMed]

93. Cho, M.; Park, G.-M.; Kim, S.-N.; Amna, T.; Lee, S.; Shin, W.-S. Glioblastoma-specific anticancer activity of pheophorbide a from the edible red seaweed Grateloupia elliptica. J. Microbiol. Biotechnol. 2014, 24, 346-353. [CrossRef]

94. Koyanagi, S.; Tanigawa, N.; Nakagawa, H.; Soeda, S.; Shimeno, H. Oversulfation of fucoidan enhances its anti-angiogenic and antitumor activities. Biochem. Pharmacol. 2003, 65, 173-179. [CrossRef]

95. Sadeeshkumar, V.; Duraikannu, A.; Ravichandran, S.; Kodisundaram, P.; Fredrick, W.S.; Gobalakrishnan, R. Modulatory efficacy of dieckol on xenobiotic-metabolizing enzymes, cell proliferation, apoptosis, invasion and angiogenesis during NDEA-induced rat hepatocarcinogenesis. Mol. Cell. Biochem. 2017, 433, 195-204. [CrossRef] 
96. Xue, M.; Ji, X.; Xue, C.; Liang, H.; Ge, Y.; He, X.; Zhang, L.; Bian, K.; Zhang, L. Caspase-dependent and caspase-independent induction of apoptosis in breast cancer by fucoidan via the PI3K/AKT/GSK3 $\beta$ pathway in vivo and in vitro. Biomed. Pharmacother. 2017, 94, 898-908. [CrossRef] [PubMed]

97. Abd-Ellatef, G.-E.F.; Ahmed, O.M.; Abdel-Reheim, E.S.; Abdel-Hamid, A.-H.Z. Ulva lactuca polysaccharides prevent Wistar rat breast carcinogenesis through the augmentation of apoptosis, enhancement of antioxidant defense system, and suppression of inflammation. Breast Cancer Targets Ther. 2017, 9, 67.

98. Lins, K.O.; Bezerra, D.P.; Alves, A.P.N.; Alencar, N.M.; Lima, M.W.; Torres, V.M.; Farias, W.R.; Pessoa, C.; de Moraes, M.O.; Costa-Lotufo, L.V. Antitumor properties of a sulfated polysaccharide from the red seaweed Champia feldmannii (Diaz-Pifferer). J. Appl. Toxicol. 2009, 29, 20-26. [CrossRef]

99. Wang, Z.-J.; Xu, W.; Liang, J.-W.; Wang, C.-S.; Kang, Y. Effect of fucoidan on B16 murine melanoma cell melanin formation and apoptosis. Afr. J. Tradit. Complement. Altern. Med. 2017, 14, 149-155. [CrossRef]

100. Kang, Y.; Li, H.; Wu, J.; Xu, X.; Sun, X.; Zhao, X.; Xu, N. Transcriptome profiling reveals the antitumor mechanism of polysaccharide from marine algae Gracilariopsis lemaneiformis. PLoS ONE 2016, 11, e0158279. [CrossRef]

101. Teruya, T.; Konishi, T.; Uechi, S.; Tamaki, H.; Tako, M. Anti-proliferative activity of oversulfated fucoidan from commercially cultured Cladosiphon okamuranus TOKIDA in U937 cells. Int. J. Biol. Macromol. 2007, 41, 221-226. [CrossRef] [PubMed]

102. Kim, E.J.; Park, S.Y.; Lee, J.-Y.; Park, J.H.Y. Fucoidan present in brown algae induces apoptosis of human colon cancer cells. BMC Gastroenterol. 2010, 10, 96. [CrossRef] [PubMed]

103. Kim, I.H.; Kwon, M.J.; Nam, T.J. Differences in cell death and cell cycle following fucoidan treatment in high-density HT-29 colon cancer cells. Mol. Med. Rep. 2017, 15, 4116-4122. [CrossRef] [PubMed]

104. Park, H.-K.; Kim, I.-H.; Kim, J.; Nam, T.-J. Induction of apoptosis and the regulation of ErbB signaling by laminarin in HT-29 human colon cancer cells. Int. J. Mol. Med. 2013, 32, 291-295. [CrossRef] [PubMed]

105. Jung, H.A.; Jung, H.J.; Jeong, H.Y.; Kwon, H.J.; Ali, M.Y.; Choi, J.S. Phlorotannins isolated from the edible brown alga Ecklonia stolonifera exert anti-adipogenic activity on 3T3-L1 adipocytes by downregulating C/EBP $\alpha$ and PPAR $\gamma$. Fitoterapia 2014, 92, 260-269. [CrossRef]

106. O’sullivan, A.; O'callaghan, Y.; O’grady, M.; Queguineur, B.; Hanniffy, D.; Troy, D.; Kerry, J.; O’brien, N. In vitro and cellular antioxidant activities of seaweed extracts prepared from five brown seaweeds harvested in spring from the west coast of Ireland. Food Chem. 2011, 126, 1064-1070. [CrossRef]

107. Ermakova, S.; Sokolova, R.; Kim, S.-M.; Um, B.-H.; Isakov, V.; Zvyagintseva, T. Fucoidans from brown seaweeds Sargassum hornery, Eclonia cava, Costaria costata: Structural characteristics and anticancer activity. Appl. Biochem. Biotechnol. 2011, 164, 841-850. [CrossRef]

108. Abad, M.J.; Bedoya, L.M.; Bermejo, P. Natural marine anti-inflammatory products. Mini Rev. Med. Chem. 2008, 8, 740-754. [CrossRef]

109. D’Orazio, N.; Gammone, M.A.; Gemello, E.; De Girolamo, M.; Cusenza, S.; Riccioni, G. Marine bioactives: Pharmacological properties and potential applications against inflammatory diseases. Mar. Drugs 2012, 10, 812-833. [CrossRef]

110. Chaves, L.d.S.; Nicolau, L.A.D.; Silva, R.O.; Barros, F.C.N.; Freitas, A.L.P.; Aragão, K.S.; Ribeiro, R.d.A.; Souza, M.H.L.P.; Barbosa, A.L.d.R.; Medeiros, J.-V.R. Antiinflammatory and antinociceptive effects in mice of a sulfated polysaccharide fraction extracted from the marine red algae Gracilaria caudata. Immunopharmacol. Immunotoxicol. 2013, 35, 93-100. [CrossRef]

111. Ananthi, S.; Raghavendran, H.R.B.; Sunil, A.G.; Gayathri, V.; Ramakrishnan, G.; Vasanthi, H.R. In vitro antioxidant and in vivo anti-inflammatory potential of crude polysaccharide from Turbinaria ornata (Marine Brown Alga). Food Chem. Toxicol. 2010, 48, 187-192. [CrossRef] [PubMed]

112. Ku, C.S.; Pham, T.X.; Park, Y.; Kim, B.; Shin, M.S.; Kang, I.; Lee, J. Edible blue-green algae reduce the production of proinflammatory cytokines by inhibiting NF-kB pathway in macrophages and splenocytes. Biochim. Biophys. Acta (BBA) Gen. Subj. 2013, 1830, 2981-2988. [CrossRef] [PubMed]

113. Romay, C.; Armesto, J.; Remirez, D.; Gonzalez, R.; Ledon, N.; Garcia, I. Antioxidant and anti-inflammatory properties of C-phycocyanin from blue-green algae. Inflamm. Res. 1998, 47, 36-41. [CrossRef] [PubMed]

114. Shih, C.-M.; Cheng, S.-N.; Wong, C.-S.; Kuo, Y.-L.; Chou, T.-C. Antiinflammatory and antihyperalgesic activity of C-phycocyanin. Anesth. Analg. 2009, 108, 1303-1310. [CrossRef]

115. Jin, D.-Q.; Lim, C.S.; Sung, J.-Y.; Choi, H.G.; Ha, I.; Han, J.-S. Ulva conglobata, a marine algae, has neuroprotective and anti-inflammatory effects in murine hippocampal and microglial cells. Neurosci. Lett. 2006, 402, 154-158. [CrossRef]

116. Renju, G.; Muraleedhara Kurup, G.; Saritha Kumari, C. Anti-inflammatory activity of lycopene isolated from Chlorella marina on Type II Collagen induced arthritis in Sprague Dawley rats. Immunopharmacol. Immunotoxicol. 2013, 35, 282-291. [CrossRef]

117. Caroprese, M.; Albenzio, M.; Ciliberti, M.G.; Francavilla, M.; Sevi, A. A mixture of phytosterols from Dunaliella tertiolecta affects proliferation of peripheral blood mononuclear cells and cytokine production in sheep. Vet. Immunol. Immunopathol. 2012, 150, 27-35. [CrossRef]

118. Shin, E.-S.; Hwang, H.-J.; Kim, I.-H.; Nam, T.-J. A glycoprotein from Porphyra yezoensis produces anti-inflammatory effects in liposaccharide-stimulated macrophages via the TLR4 signaling pathway. Int. J. Mol. Med. 2011, 28, 809-815.

119. Kim, M.M.; Rajapakse, N.; Kim, S.K. Anti-inflammatory effect of Ishige okamurae ethanolic extract via inhibition of NF- $\mathrm{B}$ transcription factor in RAW 264.7 cells. Phytother. Res. Int. J. Devoted Pharmacol. Toxicol. Eval. Nat. Prod. Deriv. 2009, 23, 628-634. 
120. Kim, S.H.; Lim, J.W.; Kim, H. Astaxanthin inhibits mitochondrial dysfunction and interleukin-8 expression in Helicobacter pylori-infected gastric epithelial cells. Nutrients 2018, 10, 1320. [CrossRef]

121. Dore, C.M.P.G.; Alves, M.G.d.C.F.; Will, L.S.E.P.; Costa, T.G.; Sabry, D.A.; de Souza Rêgo, L.A.R.; Accardo, C.M.; Rocha, H.A.O.; Filgueira, L.G.A.; Leite, E.L. A sulfated polysaccharide, fucans, isolated from brown algae Sargassum vulgare with anticoagulant, antithrombotic, antioxidant and anti-inflammatory effects. Carbohydr. Polym. 2013, 91, 467-475. [CrossRef] [PubMed]

122. Cavalcante-Silva, L.H.A.; Barbosa Brito da Matta, C.; De Araújo, M.V.; Barbosa-Filho, J.M.; Pereira de Lira, D.; de Oliveira Santos, B.V.; De Miranda, G.E.C.; Alexandre-Moreira, M.S. Antinociceptive and anti-inflammatory activities of crude methanolic extract of red alga Bryothamnion triquetrum. Mar. Drugs 2012, 10, 1977-1992. [CrossRef] [PubMed]

123. Lee, H.-J.; Kang, G.-J.; Yang, E.-J.; Park, S.-S.; Yoon, W.-J.; Jung, J.H.; Kang, H.-K.; Yoo, E.-S. Two enone fatty acids isolated from Gracilaria verrucosa suppress the production of inflammatory mediators by down-regulating NF- $\mathrm{KB}$ and STAT1 activity in lipopolysaccharide-stimulated Raw 264.7 cells. Arch. Pharmacal Res. 2009, 32, 453-462. [CrossRef] [PubMed]

124. Bergé, J.; Debiton, E.; Dumay, J.; Durand, P.; Barthomeuf, C. In vitro anti-inflammatory and anti-proliferative activity of sulfolipids from the red alga Porphyridium cruentum. J. Agric. Food Chem. 2002, 50, 6227-6232. [CrossRef] [PubMed]

125. Song, W.; Wang, Z.; Zhang, X.; Li, Y. Ethanol extract from Ulva prolifera prevents high-fat diet-induced insulin resistance, oxidative stress, and inflammation response in mice. BioMed Res. Int. 2018, 2018, 1374565. [CrossRef] [PubMed]

126. Pangestuti, R.; Kim, S.-K. Biological activities and health benefit effects of natural pigments derived from marine algae. J. Funct. Foods 2011, 3, 255-266. [CrossRef]

127. Yoon, W.-J.; Heo, S.-J.; Han, S.-C.; Lee, H.-J.; Kang, G.-J.; Kang, H.-K.; Hyun, J.-W.; Koh, Y.-S.; Yoo, E.-S. Anti-inflammatory effect of sargachromanol G isolated from Sargassum siliquastrum in RAW 264.7 cells. Arch. Pharmacal Res. 2012, 35, 1421-1430. [CrossRef] [PubMed]

128. Kim, M.-M.; Kim, S.-K. Effect of phloroglucinol on oxidative stress and inflammation. Food Chem. Toxicol. 2010, 48, $2925-2933$. [CrossRef]

129. Lim, C.S.; Jin, D.-Q.; Sung, J.-Y.; Lee, J.H.; Choi, H.G.; Ha, I.; Han, J.-S. Antioxidant and anti-inflammatory activities of the methanolic extract of Neorhodomela aculeate in hippocampal and microglial cells. Biol. Pharm. Bull. 2006, 29, 1212-1216. [CrossRef]

130. Riccardi, G.; Rivellese, A.A. Effects of dietary fiber and carbohydrate on glucose and lipoprotein metabolism in diabetic patients. Diabetes Care 1991, 14, 1115-1125. [CrossRef]

131. Gupta, P.; Bala, M.; Gupta, S.; Dua, A.; Dabur, R.; Injeti, E.; Mittal, A. Efficacy and risk profile of anti-diabetic therapies: Conventional vs traditional drugs-A mechanistic revisit to understand their mode of action. Pharmacol. Res. 2016, 113, 636-674 [CrossRef] [PubMed]

132. Unnikrishnan, P.S.; Jayasri, M.A. Marine algae as a prospective source for antidiabetic compounds-A brief review. Curr. Diabetes Rev. 2018, 14, 237-245. [CrossRef] [PubMed]

133. Cheng, Y.; Sibusiso, L.; Hou, L.; Jiang, H.; Chen, P.; Zhang, X.; Wu, M.; Tong, H. Sargassum fusiforme fucoidan modifies the gut microbiota during alleviation of streptozotocin-induced hyperglycemia in mice. Int. J. Biol. Macromol. 2019, 131, 1162-1170. [CrossRef] [PubMed]

134. Daub, C.D.; Mabate, B.; Malgas, S.; Pletschke, B.I. Fucoidan from Ecklonia maxima is a powerful inhibitor of the diabetes-related enzyme, $\alpha$-glucosidase. Int. J. Biol. Macromol. 2020, 151, 412-420. [CrossRef]

135. Kim, K.-T.; Rioux, L.-E.; Turgeon, S.L. Alpha-amylase and alpha-glucosidase inhibition is differentially modulated by fucoidan obtained from Fucus vesiculosus and Ascophyllum nodosum. Phytochemistry 2014, 98, 27-33. [CrossRef]

136. Wang, D.; Zhao, X.; Liu, Y. Hypoglycemic and hypolipidemic effects of a polysaccharide from flower buds of Lonicera japonica in streptozotocin-induced diabetic rats. Int. J. Biol. Macromol. 2017, 102, 396-404. [CrossRef]

137. Kim, K.-J.; Yoon, K.-Y.; Lee, B.-Y. Fucoidan regulate blood glucose homeostasis in C57BL/KSJ m+/ + db and C57BL/KSJ db/db mice. Fitoterapia 2012, 83, 1105-1109. [CrossRef]

138. Kumar, T.V.; Lakshmanasenthil, S.; Geetharamani, D.; Marudhupandi, T.; Suja, G.; Suganya, P. Fucoidan-A $\alpha$-d-glucosidase inhibitor from Sargassum wightii with relevance to type 2 diabetes mellitus therapy. Int. J. Biol. Macromol. 2015, 72, 1044-1047. [CrossRef]

139. Moon, H.E.; Islam, M.N.; Ahn, B.R.; Chowdhury, S.S.; Sohn, H.S.; Jung, H.A.; Choi, J.S. Protein tyrosine phosphatase 1B and $\alpha$-glucosidase inhibitory phlorotannins from edible brown algae, Ecklonia stolonifera and Eisenia bicyclis. Biosci. Biotechnol. Biochem. 2011, 75, 1472-1480. [CrossRef]

140. Lee, S.H.; Karadeniz, F.; Kim, M.M.; Kim, S.K. $\alpha$-Glucosidase and $\alpha$-amylase inhibitory activities of phloroglucinal derivatives from edible marine brown alga, Ecklonia cava. J. Sci. Food Agric. 2009, 89, 1552-1558. [CrossRef]

141. Kang, C.; Jin, Y.B.; Lee, H.; Cha, M.; Sohn, E.-T.; Moon, J.; Park, C.; Chun, S.; Jung, E.-S.; Hong, J.-S. Brown alga Ecklonia cava attenuates type 1 diabetes by activating AMPK and Akt signaling pathways. Food Chem. Toxicol. 2010, 48, 509-516. [CrossRef] [PubMed]

142. Lee, S.-H.; Min, K.-H.; Han, J.-S.; Lee, D.-H.; Park, D.-B.; Jung, W.-K.; Park, P.-J.; Jeon, B.-T.; Kim, S.-K.; Jeon, Y.-J. Effects of brown alga, Ecklonia cava on glucose and lipid metabolism in C57BL/KsJ-db/db mice, a model of type 2 diabetes mellitus. Food Chem. Toxicol. 2012, 50, 575-582. [CrossRef]

143. Min, K.-H.; Kim, H.-J.; Jeon, Y.-J.; Han, J.-S. Ishige okamurae ameliorates hyperglycemia and insulin resistance in C57BL/KsJ$\mathrm{db} / \mathrm{db}$ mice. Diabetes Res. Clin. Pract. 2011, 93, 70-76. [CrossRef] [PubMed] 
144. Lee, Y.S.; Shin, K.H.; Kim, B.-K.; Lee, S. Anti-Diabetic activities of fucosterol fromPelvetia siliquosa. Arch. Pharmacal Res. 2004, 27, 1120-1122. [CrossRef] [PubMed]

145. Nwosu, F.; Morris, J.; Lund, V.A.; Stewart, D.; Ross, H.A.; McDougall, G.J. Anti-proliferative and potential anti-diabetic effects of phenolic-rich extracts from edible marine algae. Food Chem. 2011, 126, 1006-1012. [CrossRef]

146. Kimura, Y.; Watanabe, K.; Okuda, H. Effects of soluble sodium alginate on cholesterol excretion and glucose tolerance in rats J. Ethnopharmacol. 1996, 54, 47-54. [CrossRef]

147. Jung, H.A.; Yoon, N.Y.; Woo, M.-H.; Choi, J.S. Inhibitory activities of extracts from several kinds of seaweeds and phlorotannins from the brown alga Ecklonia stolonifera on glucose-mediated protein damage and rat lens aldose reductase. Fish. Sci. 2008, 74, 1363-1365. [CrossRef]

148. Peng, J.; Yuan, J.-P.; Wu, C.-F.; Wang, J.-H. Fucoxanthin, a marine carotenoid present in brown seaweeds and diatoms: Metabolism and bioactivities relevant to human health. Mar. Drugs 2011, 9, 1806-1828. [CrossRef]

149. Jung, H.A.; Islam, M.N.; Lee, C.M.; Oh, S.H.; Lee, S.; Jung, J.H.; Choi, J.S. Kinetics and molecular docking studies of an antidiabetic complication inhibitor fucosterol from edible brown algae Eisenia bicyclis and Ecklonia stolonifera. Chem. Biol. Interact. 2013, 206, 55-62. [CrossRef]

150. Shi, D.; Guo, S.; Jiang, B.; Guo, C.; Wang, T.; Zhang, L.; Li, J. HPN, a synthetic analogue of bromophenol from red alga Rhodomela confervoides: Synthesis and anti-diabetic effects in C57BL/KsJ-db/db mice. Mar. Drugs 2013, 11, 350-362. [CrossRef]

151. Yamazaki, H.; Nakazawa, T.; Sumilat, D.A.; Takahashi, O.; Ukai, K.; Takahashi, S.; Namikoshi, M. Euryspongins A-C, three new unique sesquiterpenes from a marine sponge Euryspongia sp. Bioorg. Med. Chem. Lett. 2013, 23, 2151-2154. [CrossRef]

152. Nuño, K.; Villarruel-López, A.; Puebla-Pérez, A.; Romero-Velarde, E.; Puebla-Mora, A.; Ascencio, F. Effects of the marine microalgae Isochrysis galbana and Nannochloropsis oculata in diabetic rats. J. Funct. Foods 2013, 5, 106-115. [CrossRef]

153. Lee, S.-H.; Jeon, Y.-J. Anti-diabetic effects of brown algae derived phlorotannins, marine polyphenols through diverse mechanisms. Fitoterapia 2013, 86, 129-136. [CrossRef] [PubMed]

154. Guan, J.; Cui, Z.; Lee, D.; Lee, Y.; Park, D. Effect of dieckol from Ecklonia cava on glucose transport in L6 muscle cells. Planta Med. 2011, 77, PH3. [CrossRef]

155. Lee, S.-H.; Park, M.-H.; Heo, S.-J.; Kang, S.-M.; Ko, S.-C.; Han, J.-S.; Jeon, Y.-J. Dieckol isolated from Ecklonia cava inhibits $\alpha$-glucosidase and $\alpha$-amylase in vitro and alleviates postprandial hyperglycemia in streptozotocin-induced diabetic mice. Food Chem. Toxicol. 2010, 48, 2633-2637. [CrossRef] [PubMed]

156. Heo, S.-J.; Hwang, J.-Y.; Choi, J.-I.; Han, J.-S.; Kim, H.-J.; Jeon, Y.-J. Diphlorethohydroxycarmalol isolated from Ishige okamurae, a brown algae, a potent $\alpha$-glucosidase and $\alpha$-amylase inhibitor, alleviates postprandial hyperglycemia in diabetic mice. Eur. J. Pharmacol. 2009, 615, 252-256. [CrossRef] [PubMed]

157. Celikler, S.; Tas, S.; Vatan, O.; Ziyanok-Ayvalik, S.; Yildiz, G.; Bilaloglu, R. Anti-hyperglycemic and antigenotoxic potential of Ulva rigida ethanolic extract in the experimental diabetes mellitus. Food Chem. Toxicol. 2009, 47, 1837-1840. [CrossRef]

158. Sun, Z.; Peng, X.; Liu, J.; Fan, K.-W.; Wang, M.; Chen, F. Inhibitory effects of microalgal extracts on the formation of advanced glycation endproducts (AGEs). Food Chem. 2010, 120, 261-267. [CrossRef]

159. Abdelsalam, S.S.; Korashy, H.M.; Zeidan, A.; Agouni, A. The role of protein tyrosine phosphatase (PTP)-1B in cardiovascular disease and its interplay with insulin resistance. Biomolecules 2019, 9, 286. [CrossRef]

160. Lee, J.Y.; Kim, S.M.; Jung, W.-S.; Song, D.-G.; Um, B.-H.; Son, J.-K.; Pan, C.-H. Phlorofucofuroeckol-A, a potent inhibitor of aldo-keto reductase family 1 member B10, from the edible brown alga Eisenia bicyclis. J. Korean Soc. Appl. Biol. Chem. 2012, 55, 721-727. [CrossRef]

161. Gunathilaka, M.; Ranasinghe, P.; Samarakoon, K.; Peiris, L. In-vitro anti-diabetic activity of polyphenole-rich extract from marine brown algae Choonospora minima (Hering 1841). In Proceedings of the 12th International Conference of KDU, General Sri John Kotelawala University, Kandawala, Sri Lanka, 11-12 September 2019; p. 185.

162. Son, Y.K.; Jin, S.E.; Kim, H.-R.; Woo, H.C.; Jung, H.A.; Choi, J.S. Inhibitory activities of the edible brown alga Laminaria japonica on glucose-mediated protein damage and rat lens aldose reductase. Fish. Sci. 2011, 77, 1069-1079. [CrossRef]

163. Yang, H.-W.; Fernando, K.; Oh, J.-Y.; Li, X.; Jeon, Y.-J.; Ryu, B. Anti-obesity and anti-diabetic effects of Ishige okamurae. Mar. Drugs 2019, 17, 202. [CrossRef] [PubMed]

164. Ali, M.; Kim, D.H.; Seong, S.H.; Kim, H.-R.; Jung, H.A.; Choi, J.S. $\alpha$-Glucosidase and protein tyrosine phosphatase 1B inhibitory activity of plastoquinones from marine brown alga Sargassum serratifolium. Mar. Drugs 2017, 15, 368. [CrossRef] [PubMed]

165. Lopez-Santamarina, A.; Miranda, J.M. Potential Use of Marine Seaweeds as Prebiotics: A Review. Molecules 2020, $25,1004$. [CrossRef] [PubMed]

166. Kim, M.H.; Kang, S.G.; Park, J.H.; Yanagisawa, M.; Kim, C.H. Short-chain fatty acids activate GPR41 and GPR43 on intestinal epithelial cells to promote inflammatory responses in mice. Gastroenterology 2013, 145, 396-406.e1-10. [CrossRef]

167. Cavaglieri, C.R.; Nishiyama, A.; Fernandes, L.C.; Curi, R.; Miles, E.A.; Calder, P.C. Differential effects of short-chain fatty acids on proliferation and production of pro-and anti-inflammatory cytokines by cultured lymphocytes. Life Sci. 2003, 73, 1683-1690. [CrossRef]

168. Sun, Y.; Liu, Y.; Ai, C.; Song, S.; Chen, X. Caulerpa lentillifera polysaccharides enhance the immunostimulatory activity in immunosuppressed mice in correlation with modulating gut microbiota. Food Funct. 2019, 10, 4315-4329. [CrossRef]

169. Zhang, W.; Oda, T.; Yu, Q.; Jin, J.-O. Fucoidan from Macrocystis pyrifera has powerful immune-modulatory effects compared to three other fucoidans. Mar. Drugs 2015, 13, 1084-1104. [CrossRef] 
170. Ale, M.T.; Maruyama, H.; Tamauchi, H.; Mikkelsen, J.D.; Meyer, A.S. Fucoidan from Sargassum sp. and Fucus vesiculosus reduces cell viability of lung carcinoma and melanoma cells in vitro and activates natural killer cells in mice in vivo. Int. J. Biol. Macromol. 2011, 49, 331-336. [CrossRef]

171. Jin, J.-O.; Zhang, W.; Du, J.-Y.; Wong, K.-W.; Oda, T.; Yu, Q. Fucoidan can function as an adjuvant in vivo to enhance dendritic cell maturation and function and promote antigen-specific T cell immune responses. PLoS ONE 2014, 9, e99396. [CrossRef]

172. Negishi, H.; Mori, M.; Mori, H.; Yamori, Y. Supplementation of elderly Japanese men and women with fucoidan from seaweed increases immune responses to seasonal influenza vaccination. J. Nutr. 2013, 143, 1794-1798. [CrossRef] [PubMed] 